\title{
Aerosol composition and sources in the central Arctic Ocean during ASCOS
}

\author{
R. Y.-W. Chang ${ }^{1}$, C. Leck ${ }^{2}$, M. Graus ${ }^{3, *}$, M. Müller ${ }^{3, * *}$, J. Paatero ${ }^{4}$, J. F. Burkhart ${ }^{5,6}$, A. Stohl ${ }^{5}$, L. H. Orr ${ }^{2}$, \\ K. Hayden ${ }^{7}$, S.-M. Li ${ }^{7}$, A. Hansel ${ }^{3}$, M. Tjernström ${ }^{2,8}$, W. R. Leaitch ${ }^{7}$, and J. P. D. Abbatt ${ }^{1}$ \\ ${ }^{1}$ Department of Chemistry, University of Toronto, Toronto, Canada \\ ${ }^{2}$ Department of Meteorology, Stockholm University, Stockholm, Sweden \\ ${ }^{3}$ Institute for Ion Physics and Applied Physics, Innsbruck University, Innsbruck, Austria \\ ${ }^{4}$ Finnish Meteorological Institute, Helsinki, Finland \\ ${ }^{5}$ Norwegian Institute for Air Research (NILU), Kjeller, Norway \\ ${ }^{6}$ Sierra Nevada Research Institute, University of California, Merced, Merced, USA \\ ${ }^{7}$ Science and Technology Branch, Environment Canada, Downsview, Canada \\ ${ }^{8}$ Bert Bolin Center for Climate Research, Stockholm University, Stockholm, Sweden \\ *now at: Chemical Sciences Division, National Oceanic and Atmospheric Administration and Cooperative Institute for \\ Research in Environmental Sciences, University of Colorado, Boulder, USA \\ ** now at: Institute on Catalysis and Envrionmental Research, University of Lyon, Lyon, France
}

Received: 29 April 2011 - Published in Atmos. Chem. Phys. Discuss.: 16 May 2011

Revised: 13 October 2011 - Accepted: 14 October 2011 - Published: 27 October 2011

\begin{abstract}
Measurements of submicron aerosol chemical composition were made over the central Arctic Ocean from 5 August to 8 September 2008 as a part of the Arctic Summer Cloud Ocean Study (ASCOS) using an aerosol mass spectrometer (AMS). The median levels of sulphate and organics for the entire study were 0.051 and $0.055 \mathrm{\mu gm}^{-3}$, respectively. Positive matrix factorisation was performed on the entire mass spectral time series and this enabled marine biogenic and continental sources of particles to be separated. These factors accounted for $33 \%$ and $36 \%$ of the sampled ambient aerosol mass, respectively, and they were both predominantly composed of sulphate, with $47 \%$ of the sulphate apportioned to marine biogenic sources and $48 \%$ to continental sources, by mass. Within the marine biogenic factor, the ratio of methane sulphonate to sulphate was $0.25 \pm 0.02$, consistent with values reported in the literature. The organic component of the continental factor was more oxidised than that of the marine biogenic factor, suggesting that it had a longer photochemical lifetime than the organics in the marine biogenic factor. The remaining ambient aerosol mass was apportioned to an organic-rich factor that could have arisen from a combination of marine and continental sources. In
\end{abstract}

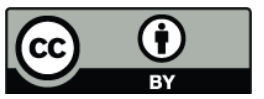

Correspondence to: J. P. D. Abbatt (jabbatt@chem.utoronto.ca) particular, given that the factor does not correlate with common tracers of continental influence, we cannot rule out that the organic factor arises from a primary marine source.

\section{Introduction}

The sources and chemical composition of Arctic aerosol are still poorly represented in models. In a recent intercomparison study of 13 models that predict transported Arctic aerosol sulphate and black carbon mass, the majority of the models did not compare well to aerosol loadings observed at three land sites (Shindell et al., 2008). In general, the models had trouble capturing the seasonality of the observed aerosol mass, underpredicting for the winter months and overpredicting for the summer months.

The observed seasonal behaviour is driven by Arctic haze, which is a phenomenon that takes place during the winter and early spring and has been observed in the northern latitudes of North America and Europe. During this time, aerosol loadings are 10-40 times higher than summertime values, with sulphate and black carbon making up the principal identified components (Barrie, 1986; Heintzenberg and Leck, 1994; Quinn et al., 2007). Models show that these particles are transported mainly from the lower latitudes of Eurasia, with a small contribution from North America, into the

Published by Copernicus Publications on behalf of the European Geosciences Union. 
central Arctic (Gong et al., 2010) and are lost more slowly because strong temperature inversions lead to reduced precipitation. As sunlight returns to the Arctic in the spring, the atmospheric stability is reduced and the particles can be lost with deposition (summarised by Quinn et al., 2007).

In contrast, during the summer, air passes over open ocean in the North Atlantic and Pacific Oceans before arriving in the Arctic. Because the air is less stable and travels more slowly with more frequent precipitation, aerosol mass transported from lower latitudes is less compared to the winter (Law and Stohl, 2007). Low summertime aerosol number concentrations have been observed, for example, over Greenland (Megaw and Flyger, 1973), on Spitsbergen (Heintzenberg and Leck, 1994) and over the central Arctic Ocean (Covert et al., 1996). Under these conditions, local aerosol sources become much more important because the concentrations of transported aerosol are so low.

A series of three previous international ice-breaker expeditions to the central Arctic Ocean (north of $85^{\circ} \mathrm{N}$ ) during the summers of 1991 (IAOE-91) (Leck et al., 1996), 1996 (AOE-96) (Leck et al., 2001) and 2001 (AOE-2001) (Leck et al., 2004; Tjernström, 2005) has greatly contributed to our knowledge of aerosol sources and composition at these northern latitudes. For example, it was observed during IAOE-91 that submicron sulphur-containing particles over the Arctic pack ice are efficiently scavenged by fogs and low clouds and have average residence times of $\approx 20 \mathrm{~h}$ (Nilsson and Leck, 2002). This was corroborated by observations from AOE-96 which found cloud condensation nuclei (CCN) concentrations to decrease as the transport time over pack ice reached $36 \mathrm{~h}$ (Bigg and Leck, 2001), consistent with loss due to wet deposition. However, this latter study also observed an increase in $\mathrm{CCN}$ concentration in air that had travelled over the pack ice for $>36 \mathrm{~h}$. Transport from the free troposphere was ruled out (Bigg and Leck, 2001) and it has been hypothesised that a local source directly emits water insoluble organic components from the surface microlayer of open leads by bubble bursting (e.g. Bigg et al., 2004; Bigg and Leck, 2008; Leck et al., 2002b; Leck and Bigg, 2010). These organics are suggested to be exopolymer secretions which are microcolloids and their gels (Leck and Bigg, 2005a). They can be viewed as three-dimensional biopolymer networks containing polysaccharides and/or monosaccharides (carbohydrates), with peptides and proteins attached to the network. These biopolymers are inter-bridged with divalent cations (such as $\mathrm{Ca}^{2+}$ ) which result in a gel-like consistency (Chin et al., 1998).

Open leads have been observed in the past to be a source of particles in the Canadian Arctic spring (Leaitch et al., 1994). In addition, observations of an organic aerosol fraction originating from the ocean have been made at lower latitudes such as Barrow, USA $\left(71^{\circ} \mathrm{N}, 156^{\circ} \mathrm{W}\right)$ and the Arctic Ocean (Hawkins and Russell, 2010; Russell et al., 2010), the North Atlantic Ocean (Ceburnis et al., 2008; Facchini et al., 2008; O'Dowd et al., 2004), as well as the southeast Pacific
(Hawkins and Russell, 2010). Depending on the location and method, these aerosol have been observed to be both water soluble (Hawkins and Russell, 2010; Russell et al., 2010) and insoluble (Bigg and Leck, 2008; Ceburnis et al., 2008; Facchini et al., 2008; Hawkins and Russell, 2010; O'Dowd et al., 2004). The chemical nature of these compounds has been reported to be similar to lipopolysaccharides, based on nuclear magnetic resonance spectra (Facchini et al., 2008); similar to simple biological sugars, based on fourier transform infrared spectra (Russell et al., 2010); and originating from proteins, amino acids and micro-organisms, based on scanning transmission X-ray microscopy with near-edge X-ray absorption fine structure (Hawkins and Russell, 2010). A detailed summary of marine organic aerosol can be found in Hawkins and Russell (2010).

There is also evidence of secondary organic products in Arctic aerosol, with the oxidation products of isoprene identified in aerosol collected at Alert, Canada $\left(83^{\circ} \mathrm{N}, 62^{\circ} \mathrm{W}\right)$ (Fu et al., 2009), which could have originated from local marine organisms emitting isoprene. Aerosol growth observed at Summit, Greenland has also been attributed to organics originating from the snow (Ziemba et al., 2010). Overall, the level of scientific understanding of the biological contributions to organic aerosol in the Arctic, as well as aerosol sources in general, is still low due to the limited amount of observational data.

These findings complement the better understood biogenic contributions to marine aerosol, including over the Arctic pack ice, of dimethyl sulphide (DMS) oxidation products. DMS is produced through the planktonic food web and emitted from the ocean into the air where it is oxidised to ultimately form, among other products, sulphuric acid and methane sulphonic acid (Yin et al., 1990a,b), both of which can end up in the condensed phase (Kreidenweis et al., 1991). Local marine biogenic sources of sulphur in aerosol have been observed at various Arctic sites such as over the Arctic pack ice (Kerminen and Leck, 2001; Leck and Persson, 1996), at Alert, Canada (Li and Barrie, 1993a,b; Norman et al., 1999), at Ny-Ålesund, Spitsbergen $\left(79^{\circ} \mathrm{N}\right.$, $\left.12^{\circ} \mathrm{E}\right)$ (Heintzenberg and Leck, 1994) and at Barrow, USA (as summarised by Quinn et al., 2009). It has been proposed that in the central Arctic Ocean, after the sulphurcontaining particles have been lost to wet deposition (Nilsson and Leck, 2002), DMS oxidation products formed further over the pack ice condense on the locally produced organic particles formed from bubble bursting (Leck et al., 2002b; Leck and Bigg, 2005b).

The physical and chemical properties of aerosol particles determine whether they can act as CCN and nucleate cloud droplets. As such, the particle sources and aging processes in the Arctic are important since they can affect their CCNactivity. Clouds at low- to mid-latitudes have a net cooling effect. At these locations, an increase in particle number concentration can result in an increase in the number of particles that act as CCN, leading to an increase in cloud droplet 
concentration and further cooling of the surface (Twomey, 1977). In the Arctic, however, because of high surface albedos and low levels of solar radiation, longwave emissions from clouds can dominate and the clouds instead warm the surface during most of the year (Shupe and Intrieri, 2004; Tjernström, 2005). Furthermore, for thin clouds under pristine conditions, as often found in the Arctic, increased particle concentrations due to pollution can lead to clouds that increase surface warming from longwave emission (Garrett et al., 2002; Garrett and Zhao, 2006; Mauritsen et al., 2011). Whether Arctic clouds have a net warming or cooling effect depends on the time of year and location (Garrett et al., 2002; Garrett and Zhao, 2006; Lubin and Vogelmann, 2007; Sedlar et al., 2010; Shupe and Intrieri, 2004; Tjernström, 2005; Wang and Key, 2003). As such, it is important that cloud forcing, formation and dispersion are well understood such that the effects of future increases in temperature and particle concentration on Arctic low-level clouds and their effects on polar climate can be projected.

This paper presents measurements of aerosol chemical composition made over the central Arctic Ocean and uses them to elucidate information about aerosol sources to contribute to our understanding of low-level stratiorm cloud formation within the boundary layer over the pack ice. These measurements were made as a part of the Arctic Summer Cloud Ocean Study (ASCOS), the overall purpose of which was to study the formation, structure, and dispersion of lowlevel stratiform clouds during the biologically-active period of the central Arctic summer and transition to autumn freezeup conditions. This question is multifaceted and the interdisciplinary team included meteorologists, oceanographers, atmospheric chemists, aerosol scientists and marine biologists. ASCOS continues observations made in the central Arctic Ocean from IAOE-91, AOE-96 and AOE-2001.

The primary measurements presented here were made with an aerosol mass spectrometer (AMS), which quantifies chemical composition of the submicron non-refractory component at high time-resolution from mass spectra. This expands on previous studies in the high Arctic and central Arctic Ocean which relied on filter or impactor measurements collected over hours to weeks (e.g. Hillamo et al., 2001; Leck and Persson, 1996; Li and Barrie, 1993a; Xie et al., 2006). Although surface AMS measurements have been made at Eureka, Canada $\left(80^{\circ} \mathrm{N}, 86^{\circ} \mathrm{W}\right)$ (Kuhn et al., 2010), this site is primarily influenced by the free troposphere and to our knowledge, this is the first time that AMS measurements have been made in the boundary layer of the central Arctic Ocean. These boundary layer data can also be compared to free tropospheric measurements made during other International Polar Year campaigns where biomass burning was found to dominate the aerosol loading (Brock et al., 2011).

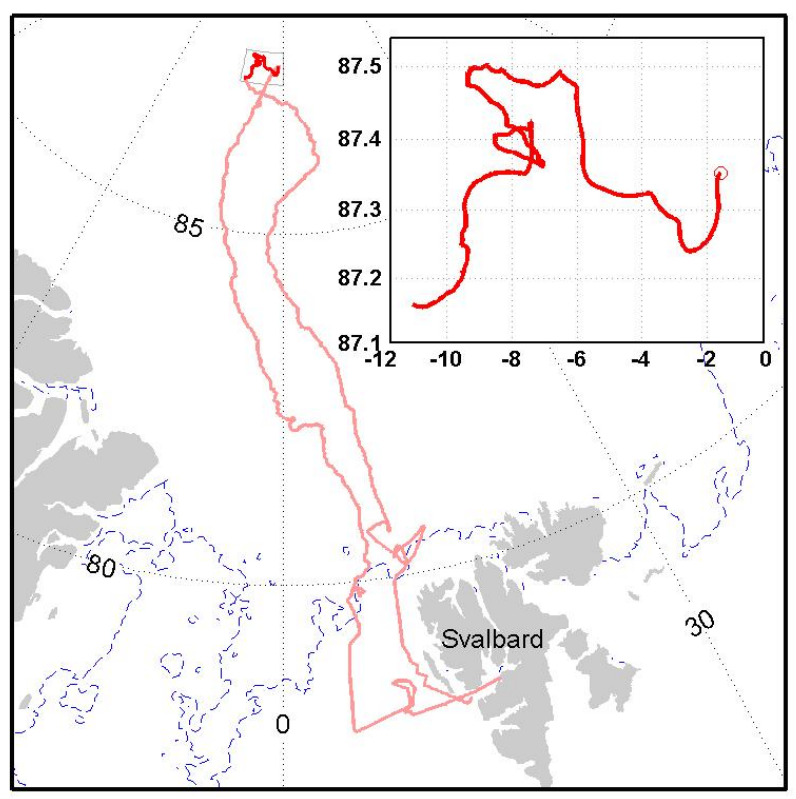

Fig. 1. Map of the ASCOS cruise track (pink) with ice-drift period highlighted (red) and shown in detail with the start of the drift marked by the circle (inset). The ice edge for the start of the drift period on 12 August 2008 is shown in the dashed blue line (courtesy of I. Brooks).

\section{Description of measurements}

\subsection{Arctic summer cloud ocean study}

The ASCOS expedition (www.ascos.se) took place on the Swedish icebreaker Oden from 2 August to 9 September 2008 (day of year, DOY 215-253). The research cruise began at Longyearbyen on Spitsbergen island, with an open water station (OW1) on 3 August 2008 0:00 to 12:00 (DOY 216-216.5) $\left(78.2^{\circ} \mathrm{N}, 7.5^{\circ} \mathrm{E}\right)$ followed by a $24 \mathrm{~h}$ station in the marginal ice zone (MIZ1) starting 4 August 2008 12:00 (DOY 217.5) $\left(79.9^{\circ} \mathrm{N}, 6.1^{\circ} \mathrm{E}\right)$. Afterwards, the ship headed north through the Arctic Ocean drifting pack ice as far as $87.4^{\circ} \mathrm{N}, 1.5^{\circ} \mathrm{W}$ on 12 August 2008 (DOY 225) when an ice camp was established on an $\approx 3 \mathrm{~km} \times 6 \mathrm{~km}$ ice floe. The Oden drifted with the ice for 21 days and departed on 2 September 2008 (DOY 246) to return southwards. A second marginal ice zone station (MIZ2) took place 6 September 2008, 09:00 to 7 September 2008, 04:00 (DOY 250.4251.2) $\left(80.7^{\circ} \mathrm{N}, 8.9^{\circ} \mathrm{E}\right)$ immediately followed by a final 12 h open water station (OW2) ending 7 September 2008, 16:00 (DOY 251.7$)\left(80.4^{\circ} \mathrm{N}, 10.1^{\circ} \mathrm{E}\right)$. All times are reported in coordinated universal time (UTC). Overall, the cruise ranged in location from $77.9^{\circ}$ to $87.5^{\circ} \mathrm{N}$ and $11.1^{\circ} \mathrm{W}$ to $9.6^{\circ} \mathrm{E}$. A map of the route with the ice drift magnified is shown in Fig. 1. 


\subsection{Aerosol mass spectrometer}

A compact time-of-flight (C-ToF) aerosol mass spectrometer (Aerodyne Research Inc.) measured the submicron aerosol non-refractory chemical composition. The instrument was located in the aerosol container on the 4th deck of the Oden and sampled from an inlet with an impactor whose $50 \%$ cutoff diameter was $10 \mu \mathrm{m}\left(\mathrm{PM}_{10}\right)$. The inlet was located $\approx 25$ $\mathrm{m}$ above sea level and the total flow through this $9 \mathrm{~cm}$ inner diameter pipe was $\approx 11001 \mathrm{~min}^{-1}$. This resulted in a residence time of $<1.4 \mathrm{~s}$ and a Reynolds number of $\sim 21000$. The turbulent flow in the main inlet ensured that the air was well-mixed when sampled by the numerous isokinetic secondary lines. The AMS sampled directly from a secondary line $(10 \mathrm{~mm} \mathrm{OD} \times 7 \mathrm{~m})$ that had a residence time of $<4 \mathrm{~s}$ and a Reynolds number of $\sim 1400$. The room temperature was at least $20 \mathrm{~K}$ warmer than ambient, resulting in an $\mathrm{RH}$ of $<30 \%$ in the lines. It is possible that the aerosol had insufficient time to effloresce, shifting the range of dry particle diameters sampled by the AMS to smaller sizes. The $\mathrm{PM}_{10}$ inlet was identical to the one used during IAOE-91, AOE-96 and AOE-2001 and details on its position and design on board the Oden are further described in Leck et al. (2001).

Particles enter the AMS through a $100 \mu \mathrm{m}$ critical orifice at 2 torr and pass through a series of aerodynamic lenses which both focus the particles into a beam and accelerate them into a vacuum chamber. Particles impact on a resistively heated ceramic oven, which flash vapourises the nonrefractory components of the aerosol at $870 \mathrm{~K}$ and $10^{-7}$ torr. The resulting gaseous compounds are ionised by electron impact $(70 \mathrm{eV})$ and detected with a unit mass resolution timeof-flight mass spectrometer. The results presented here are for the average bulk aerosol composition, which was averaged over $5 \mathrm{~min}$ intervals. Further details on the general operation of the AMS can be found in the literature (Canagaratna et al., 2007; Drewnick et al., 2005; Jayne et al., 2000; Jimenez et al., 2003).

The fragmentation table, used to identify the different contributors to the mass spectrum, was modified from the standard table (Allan et al., 2004) according to Langley et al. (2010) to include methane sulphonate (MSA). Although the fragmentation of MSA in the AMS is dependent on temperature (Zorn et al., 2008), we used the same instrument at the same oven temperature as Langley et al. (2010), reducing the effects of temperature on our results. The airbeam was corrected to the signal at mass-to-charge ratio $(\mathrm{m} / \mathrm{z}) 40$ due to non-linearities in the signal at $\mathrm{m} / \mathrm{z} 28$. An ionisation efficiency calibration with ammonium nitrate was performed at least once each week. The sample flow rate was $\approx 100 \mathrm{~cm}^{3} \mathrm{~min}^{-1}$ (STP) and was calibrated throughout the study with a bubble flow meter. Finally, a filter was put in line twice every day for blank measurements and the air peaks adjusted accordingly.

A collection efficiency of $0.6 \pm 0.2$ was calculated to correct for particles that bounce in the vapouriser and are not measured. This was the average of values obtained by two methods. The first method compared the total mass measured by the AMS with mass calculated from the number distributions measured by a differential mobility particle sizer, also sampling from the $\mathrm{PM}_{10}$ inlet, and correcting them for transmission efficiencies in the AMS according to Liu et al. (2007). A collection efficiency of 0.4 gave the best agreement using this method, assuming that the density of sulphate, nitrate, MSA and organic are 1770, 1730, 1480 and $1500 \mathrm{kgm}^{-3}$, respectively (Weast et al., 1983; Kostenidou et al., 2007). The second approach compared the AMS measurements of sulphate and MSA with the submicron stages of cascade impactors (Chang et al., 2011), also on the $\mathrm{PM}_{10}$ inlet, which resulted in a collection efficiency of 0.8. However, since the uncertainties from both methods were large, a standard collection efficiency of 0.5 was used such that our results have the same uncertainties as results reported by other AMS studies. Note that because the mass comparison between the AMS and the other instruments did not systematically change at any point during the study, the value of the collection efficiency does not affect the factor analysis presented below since only the relative values are important.

\subsection{Proton-transfer-reaction time-of-flight mass spectrometer}

DMS, acetonitrile, toluene and benzene were measured using a proton-transfer-reaction time-of-flight mass spectrometer (PTR-TOF) built at Innsbruck University. The PTR-MS technique is a well-established method for fast online volatile organic compound (VOC) analysis (Lindinger et al., 1998; de Gouw and Warneke, 2007) in the atmosphere. The instrument used in this study (employing a TOF-MS instead of a quadrupole mass analyser) was described in detail by Graus et al. (2010). The PTR-TOF was calibrated by applying a dynamically diluted VOC gas standard (Apel \& Riemer Environmenal Inc); zero-calibrations were performed every 2-6h using catalytically scrubbed air. The PTR-TOF cosampled next to the aerosol inlet through a Teflon filter and a heated $6.4 \mathrm{~mm}$ Sulfinert ${ }^{\circledR}$ (Restek Performance Coating) tubing with a residence time of $<3 \mathrm{~s}$. The PTR-TOF spectra were analysed as described by Graus et al. (2010) and Müller et al. (2010).

\subsection{Radon 222}

${ }^{222} \mathrm{Rn}$ is often used as a tracer for air that was in contact with land and was measured every hour on the 7th deck of the Oden using a U.S. Department of Homeland Security, Environmental Measurements Laboratory instrument based on the in-growth and subsequent alpha counting of short-lived ${ }^{222} \mathrm{Rn}$ progeny. The sample air was pumped through a HEPA filter which removed all the radionuclides, including shortlived ${ }^{222} \mathrm{Rn}$ progeny attached to aerosol particles. However, ${ }^{222} \mathrm{Rn}$, being a noble gas, passed through this filter. Next the 
air entered a 5001 delay chamber where part of the ${ }^{222} \mathrm{Rn}$ decayed to its short-lived daughter nuclides. These nuclides are heavy metals and were trapped by a second filter. The alpha particles emitted by the collected daughter nuclides were then counted with a scintillation detector (Hutter et al., 1995).

\subsection{Lead 210}

${ }^{210} \mathrm{~Pb}$ is a radioactive decay product of ${ }^{222} \mathrm{Rn}$ and can be used to indicate the age of the air since it was last in contact with land. High-volume aerosol samples were collected onto glass fibre filters (Munktell MGA) on the 7th deck of the Oden. The sample air flow rate was $\approx 140 \mathrm{~m}^{3} \mathrm{~h}^{-1}$ and the sampling time $24 \mathrm{~h}$. In the laboratory the exposed filters and the field blanks were assayed for ${ }^{210} \mathrm{~Pb}$ six months after the sampling with an automatic alpha/beta analyser (Mattsson et al., 1996). ${ }^{210} \mathrm{~Pb}$ activity content of the filters was calculated from the in-grown ${ }^{210}$ Po activity which was assayed with alpha counting.

\subsection{Positive matrix factorisation}

Positive matrix factorisation (PMF) is a statistical model that uses weighted least-square fitting for factor analysis (Paatero, 1997; Paatero and Tapper, 1994). It uses a bilinear model $\mathbf{X}=\mathbf{G F}+\mathbf{E}$, where $\mathbf{X}$ is a matrix of the measured values, and $\mathbf{G}$ and $\mathbf{F}$ are matrices computed by the model and represent the scores and loading, respectively. For AMS data, each row in $\mathbf{X}$ is a mass spectrum measured at a given time, with the columns representing the signal at a given $\mathrm{m} / \mathrm{z}$. In this case, $\mathbf{G}$ represents the time series and $\mathbf{F}$ the profile mass spectrum for the $p$ factors computed by the algorithm. $\mathbf{E}$ is the difference between the measured signal and that reconstructed by the product of $\mathbf{G}$ and $\mathbf{F}$ and is made up of the elements $e_{i j}$. The model adjusts $\mathbf{G}$ and $\mathbf{F}$ in order to reduce the object function $(Q)$, where

$Q=\sum_{i} \sum_{j}\left(e_{i j} / \sigma_{i j}\right)^{2}$,

and $\sigma_{i j}$ is the uncertainty for each element in the matrix $\mathbf{X}$.

For AMS measurements in continental regions, where the sources of inorganic aerosol are well understood, PMF is typically only performed on the organic aerosol mass spectrum (e.g. Lanz et al., 2007; Ulbrich et al., 2009a) in order to learn more about the sources and transformation processes of organic aerosol. However, in the Arctic, our understanding of both the inorganic and organic aerosol sources are limited. In particular, sulphate, which is an anthropogenic constituent in continental regions, also has a biogenic source in marine areas. PMF was performed on the entire aerosol mass spectrum in order to gain understanding on the sources and processes of the entire aerosol. This also allowed us to associate organic fractions to both continental and marine biogenic aerosol. PMF was also performed on only the organic mass spectrum and compared to the solutions from the entire mass spectrum. However, because the organic components of the ambient factors tend to resemble oxygenated organic aerosol (OOA), the results did not yield as much information and the solution is generally in agreement with the results from PMF of the entire mass spectrum.

The PMF2 program (Paatero, 1997) was used to analyse these data in robust mode with an outlier distance of 4 and no model error. The PMF evaluation tool kit (PET) (Ulbrich et al., 2009a) was used to prepare the data and error, execute PMF and evaluate the results. The data matrix was calculated by taking the entire aerosol mass spectrum ("All") and subtracting species that were 1) not of interest (i.e. air and water) and 2) unreliable due to high background and low signal (i.e. chloride and ammonium). The error matrix $\left(\sigma_{i j}\right)$ was calculated by adding in quadrature the errors calculated for the entire aerosol mass spectrum with those calculated for the subtracted species (Allan et al., 2003) and a minimum counting error of one ion was applied, as described by Ulbrich et al. (2009a). All of these calculations were done in nitrate equivalent mass. In total, $168 \mathrm{~m} / z$, ranging from 13 to 200 , were included in the analysis, with peaks removed due to known interference (e.g. 18, 28, 32); being constantly negative, which the algorithm would be unable to fit (e.g. 33, 34); or due to difficulty fitting (e.g. 35, 36).

\subsection{Potential source contribution function}

To identify potential source areas of the observed aerosol chemical mass at the location of the ice breaker a receptor model called potential source contribution function (PSCF) was used (Ashbaugh et al., 1985). The PSCF model combines meteorological information with the AMS data to produce probability fields for potential source regions for the observed data.

To reconstruct the air parcel movement, three dimensional back trajectory data were calculated from the re-analysis data library using the HYbrid Single-Particle Lagrangian Integrated Trajectory (HYSPLIT4) model (Draxler and Rolph, 2010; Rolph, 2010). The data originated from the National Weather Service's National Centers for Environmental Prediction's (NCEP) Global Data Assimilation System (GDAS).

Five-day back trajectories from 5 August to 8 September 2008 were re-calculated hourly during the expedition arriving in the boundary layer, $100 \mathrm{~m}$ above Oden's position. Air parcel movement was described by the co-ordinates of the endpoint of each hourly-segment of the trajectory. Then, to produce the PSCF analyses, each trajectory and its associated segment endpoints were associated with the measured 1h-median AMS aerosol or factor data.

In this study, the northern hemisphere was divided into $18^{\circ} \times 2.5^{\circ}$ grid cells. Trajectories with segment endpoints in cell $i j$ were counted as $n_{i j}$ and assumed to collect the chemical mass emitted from that cell. The probability that air from a particular grid had been transported along the trajectory to 
Oden's position is then given by $P_{i j}(A)=\frac{n_{i j}}{N}$, where $N$ is the total number of trajectory segment endpoints. If the aerosol sample connected to the trajectory has a concentration higher than a selected criterion value (here the 50th percentile of the measured aerosol mass concentration is used) it is set as high, and all segments of this trajectory are considered to be high. The probability that air from a particular grid, $i j$, has a high aerosol concentration, $m_{i j}$, is then given by $P_{i j}(B)=\frac{m_{i j}}{N}$. The conditional probability that the air passing through the $i j$-th cell had a high aerosol concentration when arriving to Oden is then given by the ratio of these two probabilities $P S C F_{i j}=\frac{P_{i j}(B)}{P_{i j}(A)}=\frac{m_{i j}}{n_{i j}}$.

To avoid errors when the total number of segment endpoints in a cell is low, only cells with at least 10 segment endpoints or more are used, and the PSCF values are multiplied with a weighting function

$$
\begin{gathered}
W\left(n_{i j}\right)=1.0 \text { when } 50 \leq n_{i j} \\
0.8 \text { when } 10 \leq n_{i j}<50 \\
0 \text { when } n_{i j}<10 .
\end{gathered}
$$

Similar approaches have been used in other PSCF studies (Hopke et al., 1995; Yli-Tuomi et al., 2003; Zhang et al., 2010).

\subsection{FLEXPART}

The study of air mass transport to the ship and identification of aerosol source regions was based on simulations with the Lagrangian particle dispersion model FLEXPART (Stohl et al., 1998, 2005) in backward mode. So-called retro-plumes (see Stohl et al., 2003) were initialised at hourly time intervals or when the ship had changed position by more than $0.2^{\circ}$ longitude or latitude since the last calculation. The simulations are based on operational data from ECMWF with a horizontal resolution of $0.5^{\circ}$ and a time resolution of $3 \mathrm{~h}$. Each simulation consists of the trajectories of 60000 "virtual" particles released in the volume of air sampled and tracked for 20 days backward in time. Stochastic fluctuations, obtained by solving Langevin equations, are superimposed on the grid-scale winds to represent transport by turbulent eddies (Stohl et al., 2005). A convection scheme is used to represent convective transport (Forster et al., 2007).

The backward simulations yield an emission sensitivity which is proportional to the residence times of the air parcels in a particular 3-D grid cell. It was calculated for a passive tracer and the value of this emission sensitivity is a measure for the simulated mixing ratio in the receptor volume that a source of unit strength in the respective grid cell would produce. The emission sensitivity of the passive tracer can also be used to display the transport history. By multiplying the emission sensitivity near the ground with an emission flux from an appropriate inventory, maps of source contributions are obtained, which can be used to identify pollution sources. Spatial integration of the source contribu- tions yields the simulated mixing ratios of the passive and aerosol-like tracers along the ship track. For emission information, the EDGAR V3.2FT2000 anthropogenic emissions inventory (Olivier and Berdowski, 2001) was used outside of North America and Europe where regional emission information was used. Emissions from biomass burning were modelled as described by Stohl et al. (2007) using fire locations detected by the moderate-resolution imaging spectrometer (MODIS) on the Aqua and Terra satellites and a landcover vegetation classification.

\subsection{Contamination from research activities}

Possible contamination events from local emissions (e.g. ship, helicopter, snowmobile) were determined by particle number concentrations measured by an ultrafine condensation particle counter (TSI 3025), toluene mixing levels measured by the PTR-TOF, wind direction (contamination suspected if $70^{\circ}$ to $290^{\circ}$, relative to the bow) and wind speed (contamination suspected if $<2 \mathrm{~ms}^{-1}$ or variable). These are excluded from the general AMS results presented below but included in the PMF analysis. This allowed the PMF algorithm to identify a Ship Emission factor and resulted in clearer separation between the factors than simply deleting suspected contamination times. However, in order to avoid these contamination events from overweighting the solutions, times when the total AMS mass exceeded $1 \mu \mathrm{gm}^{-3}$ were removed.

\section{Results and discussion}

\subsection{General AMS results}

Mass concentrations for the non-refractory components of aerosol measured by the AMS are shown in Fig. 2, with the shaded areas showing the times of the stations. These data have been corrected to STP using room temperature and pressure measurements. Table 1 shows basic descriptive statistics for the study as well as median values for the stations during which the AMS measured. Due to technical difficulties, the AMS was not operational during OW1. Detection limits were calculated for each blank filter measurement as 3 times the standard deviation for each constituent, and the average of these values was used as the detection limit for the entire campaign. These are also included in Table 1. Ammonium is not included since it was below its detection limit of 0.04 $\mu \mathrm{gm}^{-3} 86 \%$ of the time, although it was still included in the fragmentation table. This occasionally affected the organic mass concentration, causing it to be negative.

On average, sulphate and organics contributed 45 and $43 \%$ of the aerosol mass detected by the AMS, respectively, with an average MSA contribution of $8 \%$. The values for sulphate reported in this study are of non-sea salt sulphate, since sodium sulphate, found in sea salt, has a melting point of 
Table 1. 1st, 2nd and 3rd quartiles of AMS measurements, median concentrations for the four stations (see text) and detection limits. All units in $\mu \mathrm{gm}^{-3}$.

\begin{tabular}{lrrrrrrrr}
\hline & $\mathrm{Q}_{1}$ & $\mathrm{Q}_{2}$ & $\mathrm{Q}_{3}$ & MIZ1 & IF & MIZ2 & OW2 & Det. Lim. \\
\hline Organic & 0.018 & 0.055 & 0.097 & 0.13 & 0.043 & 0.10 & 0.043 & 0.03 \\
Sulphate & 0.020 & 0.051 & 0.099 & 0.084 & 0.044 & 0.012 & 0.060 & 0.008 \\
MSA & 0.004 & 0.008 & 0.015 & 0.019 & 0.007 & 0.018 & 0.010 & 0.01 \\
Nitrate & 0.0051 & 0.0043 & 0.0072 & 0.005 & 0.004 & 0.009 & 0.006 & 0.007 \\
\hline
\end{tabular}

Table 2. Summertime sulphate and MSA concentrations at various polar locations.

\begin{tabular}{|c|c|c|c|c|}
\hline $\begin{array}{l}\text { Location } \\
\text { or Study }\end{array}$ & $\begin{array}{l}\text { Sulphate } \\
\left(\mu \mathrm{gm}^{-3}\right)\end{array}$ & $\begin{array}{r}\text { MSA } \\
\left(\mu \mathrm{gm}^{-3}\right)\end{array}$ & $\begin{array}{c}\mathrm{MSA} / \mathrm{SO}_{4}^{2-} \\
(\mathrm{mol} / \mathrm{mol})\end{array}$ & Reference \\
\hline IAOE-91 & $0.0027-0.66$ & $0.0002-0.13$ & 0.22 & Leck and Persson (1996) \\
\hline AOE-96 & $0.0036-1.185$ & $0.002-0.104$ & & Kerminen and Leck (2001) \\
\hline \multirow[t]{2}{*}{ Alert, Canada } & & $0.03-0.05$ & $0.6 \pm 0.3$ & Li and Barrie (1993a) \\
\hline & $0.03-0.22$ & & $0.39 \pm 0.21$ & Norman et al. (1999) \\
\hline Ny-Ålesund, Spitsburgen & 0.39 & 0.018 & & Heintzenberg and Leck (1994) \\
\hline Palmer Station & $\leq 0.1$ & $0.0001-0.065$ & 0.61 & Berresheim et al. (1998) \\
\hline Halley Station & 0.075 & 0.042 & $0.65 \pm 0.13$ & Read et al. (2008) \\
\hline ASCOS & $\leq 0.008-0.42$ & $\leq 0.01-0.08$ & $0.25 \pm 0.02$ & This study \\
\hline
\end{tabular}

$1150 \mathrm{~K}$ (Weast et al., 1983) and would be refractory (i.e. undetected) in the AMS. In addition, based on cascade impactor measurements, submicron sea salt sulphate concentrations were negligible (Chang et al., 2011), consistent with past studies in the pack ice (e.g. Leck and Persson, 1996). The range of sulphate $\left(\leq 0.006-0.35 \mu \mathrm{gm}^{-3}\right)$ and MSA $\left(\leq 0.008-0.07 \mathrm{gm}^{-3}\right)$ in this study is generally in agreement with values measured at other polar sites as summarised in Table 2 .

In general, the two MIZ stations had higher aerosol loadings in all constituents than both the IF and OW2 stations, consistent with past Arctic Ocean expeditions (Nilsson and Leck, 2002). Aerosol MSA mass was measured during the MIZ2 station at the beginning of September, suggesting that marine biology was still active at this time. Care should be taken in interpreting statistics from the non-ice floe stations since the sampling time at the two MIZ stations and the OW station were limited to $\approx 3 \%$ and $1 \%$ of the total sampling time, respectively.

\subsection{PMF results}

A four-factor solution was chosen to best represent the variations in the aerosol mass for this data set. The time series and profiles of the factors are shown in Figs. 3 and 4, respectively. In this solution, there are three factors that describe the ambient air in the central Arctic Ocean: a Marine Biogenic factor, a Continental factor, and an Organic factor. In addition, a fourth factor describes emissions from contamination.

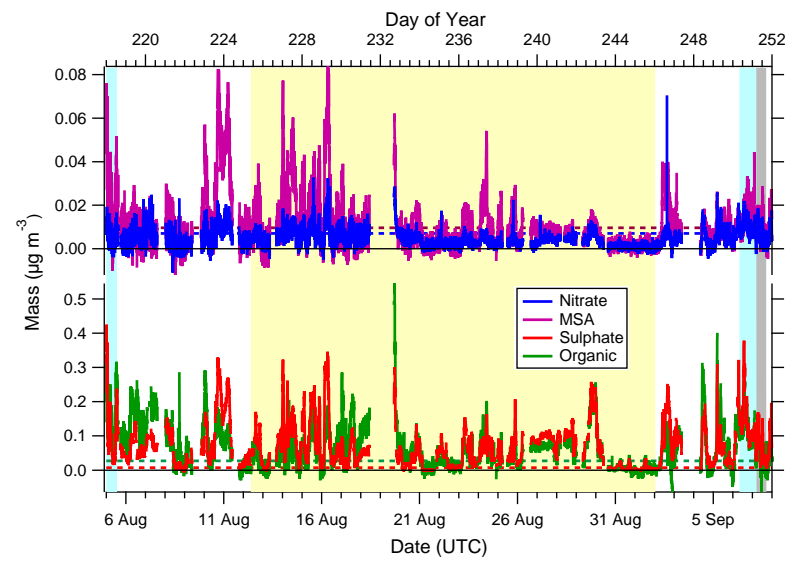

Fig. 2. Organic, sulphate, methane sulphonate (MSA) and nitrate mass concentrations (solid lines) and detection limits (dashed lines) during ASCOS. Blue, yellow and gray regions represent marginal ice zone (MIZ), ice floe (IF) and open water stations (OW), respectively.

These factors will be described in more detail in subsequent sections.

Finding the best PMF solution for a data set can be subjective. The number of factors in the solution, the robustness of these factors, and rotational ambiguities, all affect how well the variations are represented. The rotational ambiguities will be discussed here, while the details describing other 
Table 3. Composition and $\%$ contribution of factors by mass from the four-factor solution for an $f P e a k$ of -0.75 . See Figs. S2 and S3 for uncertainties. O/C calculated using the equation from Aiken et al. (2008).

\begin{tabular}{lrrrr}
\hline & F1:Marine Biogenic & F2: Continental & F3: Organic & F4: Ship Emission \\
\hline Organic (\%) & 15 & 35 & 88 & 97 \\
Sulphate (\%) & 65 & 60 & 5 & 1 \\
MSA (\%) & 16 & 3 & 3 & 2 \\
Nitrate (\%) & 4 & 2 & 5 & $<1$ \\
F44 & 0.09 & 0.25 & 0.17 & $<0.01$ \\
O/C & 0.42 & 1.1 & 0.71 & $<0.08$ \\
\% of ambient air & 33 & 36 & 31 & - \\
\hline
\end{tabular}

Table 4. Correlation coefficient of factor time series with external time traces.

\begin{tabular}{lrrr}
\hline & F1:Marine Biogenic & F2: Continental & F3: Organic \\
\hline DMS (entire study) & 0.06 & 0.23 & 0.09 \\
DMS (excluding last week) & 0.36 & -0.17 & -0.05 \\
${ }^{222} \mathrm{Rn}$ & -0.04 & 0.15 & 0.18 \\
${ }^{210} \mathrm{~Pb}$ & -0.20 & 0.66 & 0.23 \\
\hline
\end{tabular}

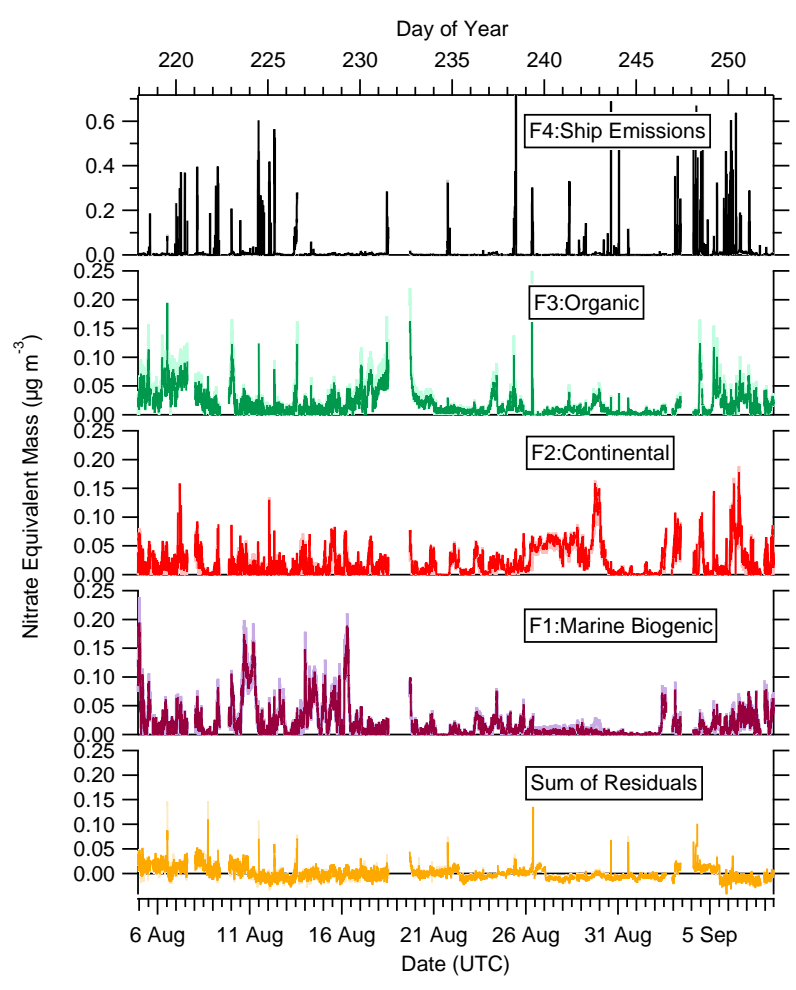

Fig. 3. Time series of the PMF factors when performed on the entire mass spectrum. The solid trace is the solution for an fPeak of -0.75 and the shaded regions the range for fPeaks of -1.5 to 0 . solutions and robustness can be found in the Supplement.

Rotational ambiguity in PMF solutions can be explored by varying the fPeak parameter. In this analysis, because the entire mass spectrum is used and because compared to continental studies there are few external time traces with which to corroborate the time series for a certain PMF solution, the best fPeak can be difficult to determine. Instead, a range of $f$ Peak values ( -1.5 to 0$)$ was found to give physically reasonable mass spectra and time series, while remaining reasonably robust. As such, the results shown here are for an fPeak of -0.75 , with the minimum and maximum of this range included to show uncertainties in the solution. In general, this uncertainty was greater than that from the robustness runs, and is considered to be more representative of the overall uncertainties.

The composition of the factors was determined by applying the fragmentation table to the profile mass spectrum of each factor. Values for an fPeak of -0.75 are shown in Table 3 , and the range due to changes in fPeak from -1.5 to 0 can be found in the Supplement. This calculation was corrected for the relative ionisation efficiencies of the different species but not to STP or for collection efficiency. It also assumes that there are no other components in the aerosol besides organics, sulphate, MSA and nitrate, and does not account for any organonitrogen or organosulphur compounds that may be present. The overall contribution of each factor, excluding the Ship Emission factor, is also given in Table 3. We see that the three ambient factors contributed approximately equally throughout the study. The next sections describe the characteristics of each factor. 


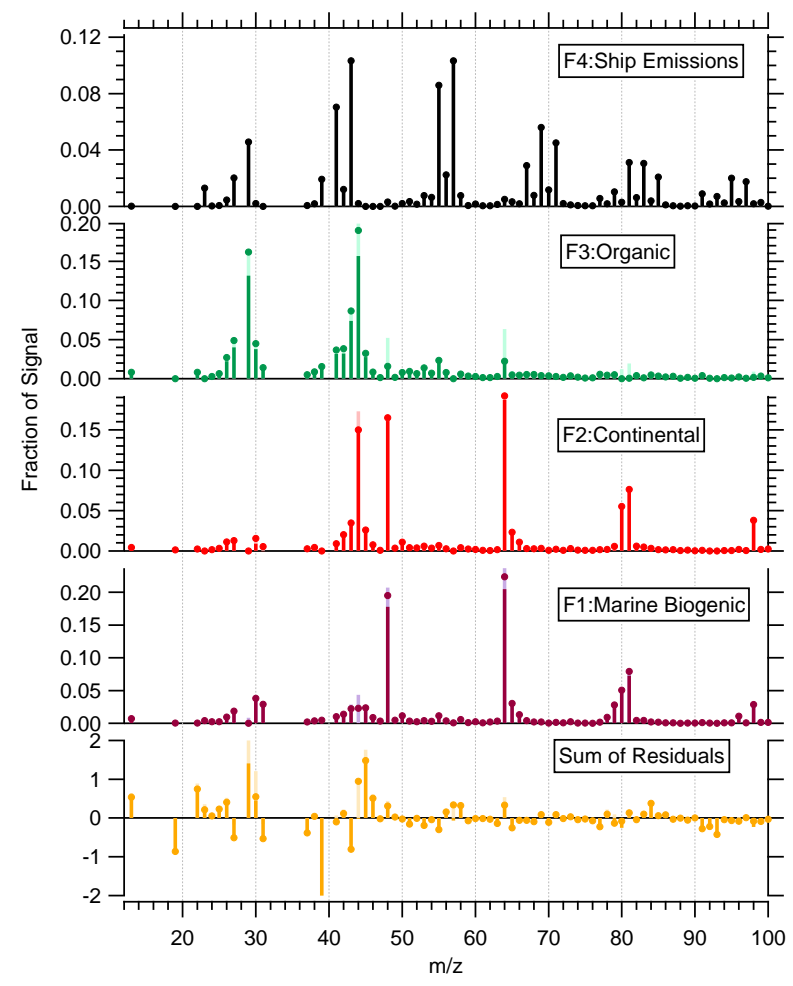

Fig. 4. Mass spectra of the PMF factors when performed on the entire mass spectrum. The circle represents the solution for an fPeak of -0.75 , and the light and solid bars the range for fPeaks of -1.5 to 0 . The signal is adjusted so that the sum of the signal for each mass spectrum is one.

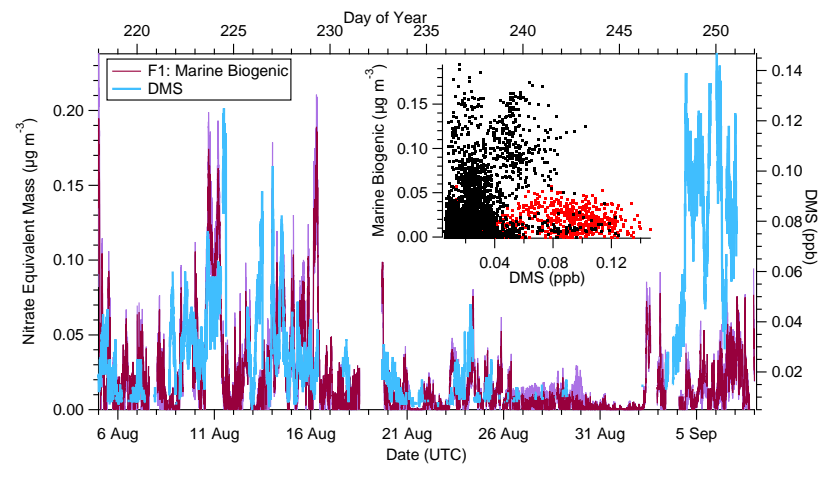

Fig. 5. Time series of the Marine Biogenic factor and DMS. The inset is a scatter plot of these two quantities, with the black points excluding the last week of the study and the red points only representing the last week of the study.

\subsubsection{Marine biogenic factor}

This factor was dominated by sulphate peaks $(\mathrm{m} / \mathrm{z}, 48,64,80$, $81,98)$ as well as MSA peaks $(\mathrm{m} / z, 79$ and 96$)$. Since MSA is only significantly formed via the photo-oxidation of DMS, which mainly originates from biological activity (Chin et al.,
1996), and $71 \%$ of the MSA mass was found in this factor, the inorganic component was attributed to secondary marine biogenic sources. The time series correlates to some degree with that of DMS (see Fig. 5 and Table 4), and improves if we exclude the last week of the study when the Oden neared the marginal ice zone and open waters $(r=0.36$, inset of Fig. 5). It is not to be expected that the particulate and gas phase products of biological activity correlate very tightly since DMS is a precursor for both sulphate and MSA and the loss processes over the pack ice are expected to be slower for DMS $(\tau \approx 3 \mathrm{~d})$ than particulate sulphate and MSA ( $\tau \approx 1 \mathrm{~d}$ ) (Nilsson and Leck, 2002). While the concentration of DMS and its oxidation product $\mathrm{SO}_{2}$ behave similarly on a seasonal and synoptic time scale, correlation on shorter time scales is not necessarily expected (Kerminen and Leck, 2001). Furthermore, previous studies in the Antarctic have found no correlation between DMS and its oxidation products (Berresheim et al., 1998; Read et al., 2008). We speculate that the measured air passed over productive waters that had both gas phase DMS and intermediate species which eventually oxidised to MSA and sulphate and condensed by the time they reached the measurement site, but that DMS had insufficient time to entirely react away. This is consistent with DMS concentrations increasing in the last week of the study while the time trace of the Marine Biogenic factor only increases slightly. As the Oden neared the open water source region, the particulate MSA and sulphate would not have had enough time to form from recent DMS emissions (Karl et al., 2007; Kerminen and Leck, 2001).

In particular, analysis of 10 and 11 August (DOY 223, 224 ) showed that the air had passed over the open ocean $\approx 1 \mathrm{~d}$ before reaching the Oden. Figure 6 shows the footprint potential emission sensitivity from FLEXPART for 11 August (DOY 224) and suggests that the air originated from the Barents sea, which, during August 2008, was ice free and biologically productive (up to $3 \mathrm{mg}$ of chlorophyll a m${ }^{-3}$ Feldman and McClain, 2008). This was generalised using PSCF analysis for this factor (Fig. 7), which shows that this factor was high when the air originated from the Barents and Kara seas.

The MSA $/ \mathrm{SO}_{4}^{2-}$ mole ratio calculated from the Marine Biogenic factor was $0.25 \pm 0.02$, with the uncertainties calculated from changes in the PMF fPeak. Table 2 shows that our value is similar to other summertime values measured in polar regions such as that calculated from submicron filter measurements during IAOE-91 (Leck and Persson, 1996) for marine biogenic times, excluding the influence of fog $(0.22)$. It is also within the lower bounds of uncertainty found by Norman et al. (1999) for Alert, Canada in July and August of 1993 and $1994(0.39 \pm 0.21)$, although lower than the 10 year record reported by $\mathrm{Li}$ and Barrie (1993a) in August also at Alert $(0.6 \pm 0.3)$. Finally, it is within the range of values calculated from a box model for conditions from AOE96 (0.32 mean, Karl et al., 2007), although lower than that predicted by a chemical transport model $(0.38-0.65$, Gondwe et al., 2004). Higher MSA / $\mathrm{SO}_{4}^{2-}$ ratios have previously 
Table 5. Correlation coefficient of factor mass spectra with reference mass spectra.

\begin{tabular}{lrrrrl}
\hline & $\begin{array}{r}\text { F1: } \\
\text { Marine }\end{array}$ & $\begin{array}{r}\text { F2: } \\
\text { Cont }\end{array}$ & $\begin{array}{r}\text { F3: } \\
\text { Org }\end{array}$ & $\begin{array}{r}\text { F4: } \\
\text { Ship }\end{array}$ & Reference \\
\hline OOA & 0.64 & 0.75 & 0.87 & 0.32 & Zhang et al. (2005a) \\
HOA & 0.46 & 0.14 & 0.37 & 0.98 & Zhang et al. (2005a) \\
Lubricating Oil & 0.39 & 0.13 & 0.30 & 0.99 & Canagaratna et al. (2004) \\
Mace Head - Organic & 0.78 & 0.97 & 0.90 & 0.18 & Ovadnevaite et al. (2011) \\
ICEALOT - OOA & 0.08 & 0.49 & 0.92 & 0.08 & Frossard et al. (2011) \\
ICEALOT - F3 & 0.19 & 0.38 & 0.84 & 0.50 & Frossard et al. (2011) \\
Glucose & 0.22 & 0.30 & 0.80 & 0.33 & Russell et al. (2010) \\
Sucrose & 0.23 & 0.27 & 0.79 & 0.39 & Russell et al. (2010) \\
\hline
\end{tabular}

been observed in the coarse mode compared to the fine mode in the Antarctic (Jefferson et al., 1998; Read et al., 2008) and in the Pacific (Phinney et al., 2006), which is thought to occur because sulphuric acid nucleates to form the smaller particles, causing methane sulphonic acid, a weaker acid to condense on the neutral coarse mode aerosol (Jefferson et al., 1998). This would be consistent with the higher ratios measured at Alert, which are of total suspended particles, whereas our measurements are for submicron particles. However, some Arctic measurements do not see a sizedependent $\mathrm{MSA}_{\mathrm{SO}} \mathrm{S}_{4}^{2-}$ (Leck and Persson, 1996). The variability in MSA/SO ${ }_{4}^{2-}$ shown in Table 2 reflects the ratio's dependence on temperature, latitude and chemistry (Barone et al., 1995; Bates et al., 1992; Hynes et al., 1986; Leck et al., 2002a; Turnipseed et al., 1996). Approximately $50 \%$ of the total sulphate mass was apportioned to this factor, with the remaining $50 \%$ apportioned to the Continental factor.

It is interesting to note that the Marine Biogenic aerosol had an organic component that was approximately equal in mass to the amount of MSA in the aerosol. The degree of oxygenation of the organic component of this factor is quite variable, with the fraction of the organic signal at $\mathrm{m} / \mathrm{z} 44$ (F44) ranging from $0-0.12$, depending on the fPeak used (see Supplement). Although at continental sites a higher F44 is interpreted as an organic component formed from secondary processes, it is possible that in polar marine environments, this organic mass is emitted as a primary aerosol that is already oxygenated, such as a mono or polysaccharide (Leck and Bigg, 2007; Russell et al., 2010). Table 5 shows that the mass spectrum of the organic component of this factor (see Fig. 8) correlates well with organic aerosol measured at Mace Head, Ireland during a biologically-productive pe$\operatorname{riod}(r=0.78)$ when the aerosol were thought to be primary marine in nature (Ovadnevaite et al., 2011) although it correlates poorly with laboratory glucose and sucrose standard solutions ( $r=0.22$ and 0.23 , respectively) (Russell et al., 2010). The organic mass spectrum also correlates reasonably with the OOA factor thought to be secondary in nature often identified at continental urban sites $(r=0.64)$ (Ulbrich et al.,

\section{Footprint Sensitivity: AIRTRACER}

Release Start: 2008-08-11 04:02:01, Release End: 2008-08-11 04:32:01

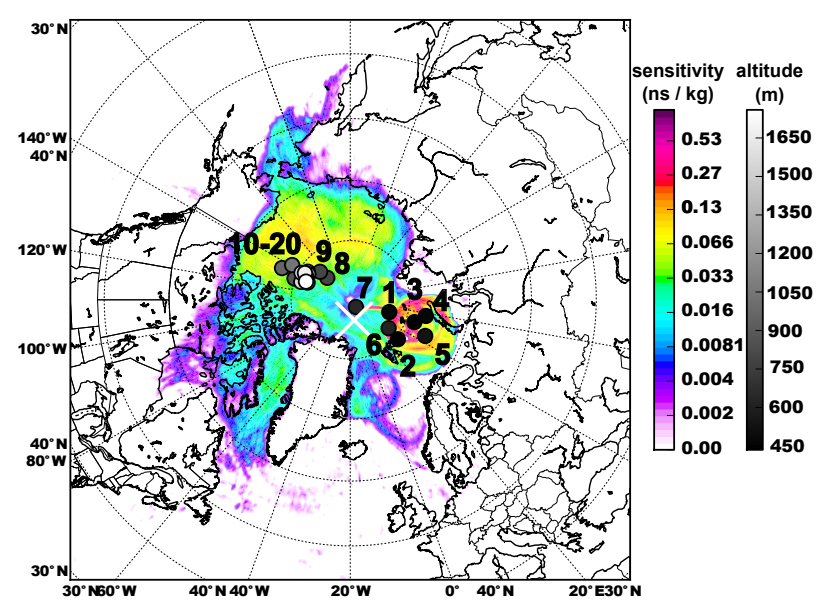

Fig. 6. FLEXPART modelled footprint potential emission sensitivity for 11 August 2008, 03:20 (DOY 224.14). The Oden's position is marked by the white cross and the numbers show that the air was influenced by the Barents sea for 6 days before arriving at the Oden.

2009b; Zhang et al., 2005a). Based on this analysis alone, it is not possible to conclude whether this organic component is formed from secondary processes (e.g. oxidation of isoprene emitted from phytoplankton) or whether it is emitted directly from the ocean through a mechanism such as bubble bursting.

\subsubsection{Continental factor}

The main feature of the time series of this factor is high signal between 26-30 August (DOY 239-243, see Fig. 3) which accounted for $\approx 1 / 3$ of the entire mass of this factor. Throughout this period the boundary layer alternated between periods where it was vertically well-mixed throughout the full boundary layer depth, and periods where the upper boundary layer, containing stratocumulus clouds, was decoupled from 


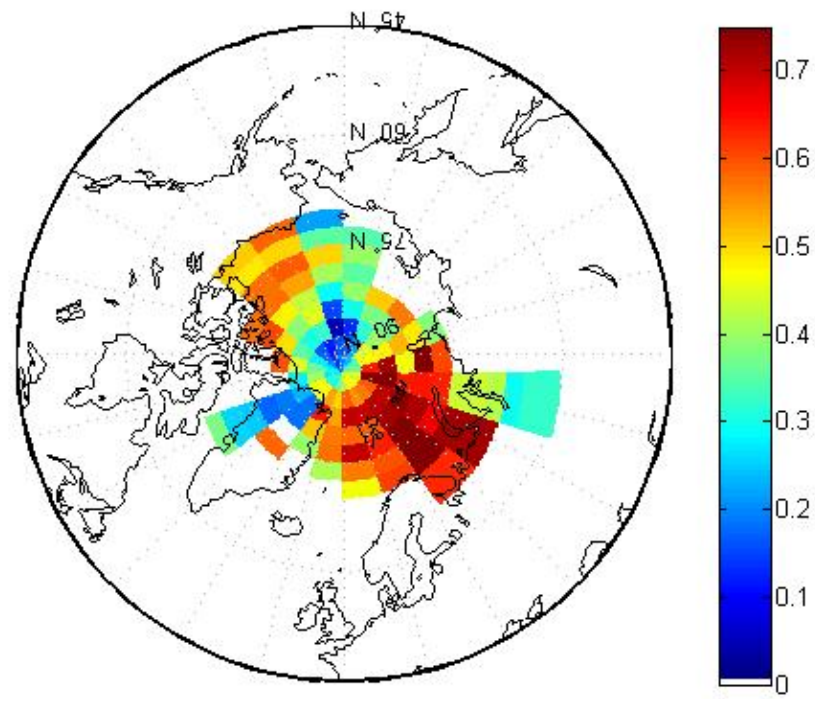

Fig. 7. PSCF analysis of the Marine Biogenic Factor.

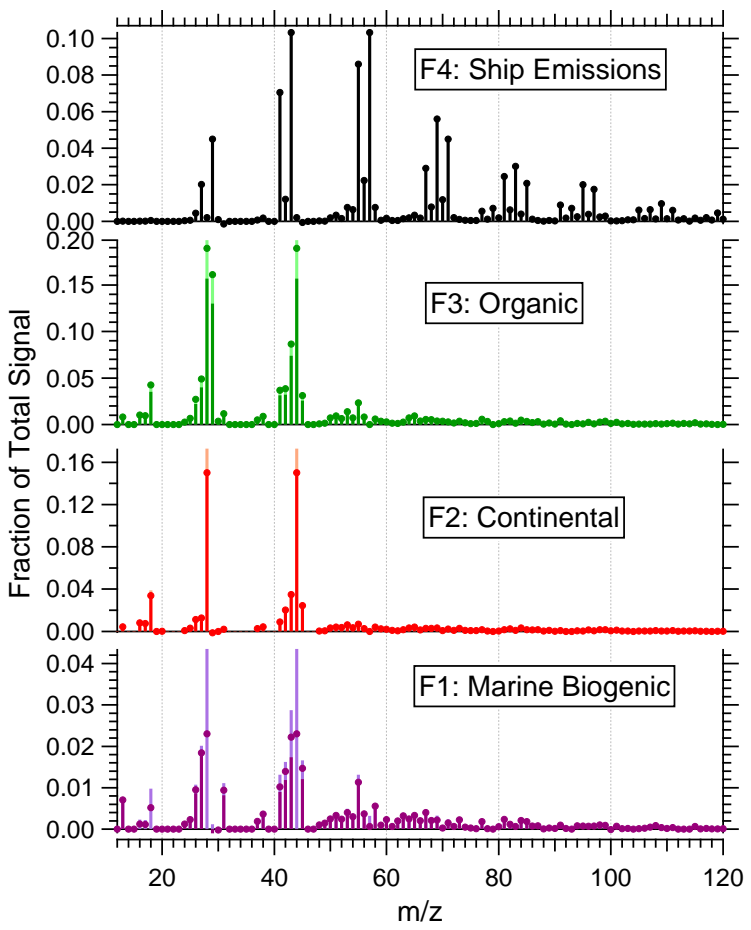

Fig. 8. Mass spectra of the organic components of the PMF factors. The circle represents the solution for an fPeak of -0.75 , and the light and solid bars the range for fPeaks of -1.5 and 0 . The signal is adjusted so that the sum of the entire signal for each mass spectrum, not only the organics, is one.

the surface by a stably stratified layer. It was decoupled on 26 and 28 August, with a shallow $(\sim 100 \mathrm{~m}$ deep) surface-based mixed layer, recoupling on 27 and 29 August. This mixing state can be clearly identified in the 6-hourly radiosonde pro-

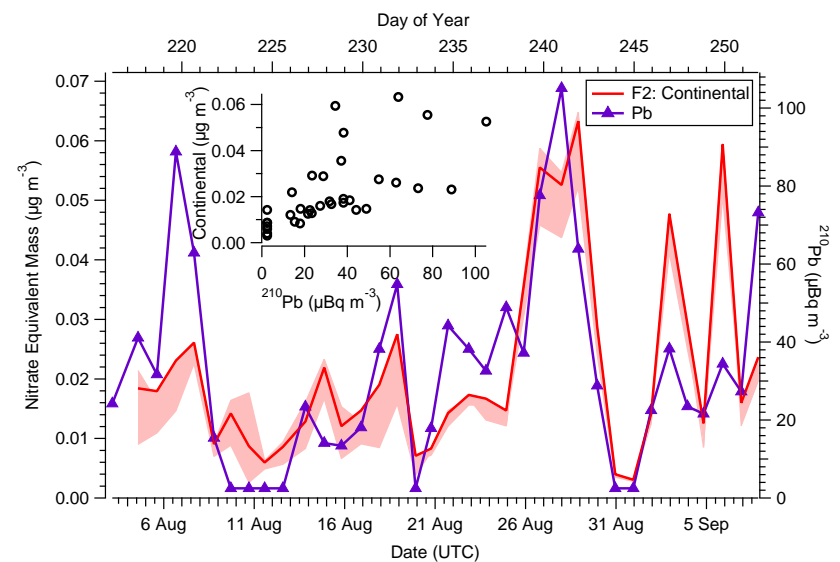

Fig. 9. Time series of the Continental Factor and ${ }^{210} \mathrm{~Pb}$. Inset shows scatterplot of these two quantities.

files, and turbulence profiles made from a tethered balloon. We speculate that the surface air that mixed with the upper part of the boundary layer was influenced by continental combustion (average acetonitrile mixing ratio of $0.080 \mathrm{pptv}$ compared to campaign-long average of $0.048 \mathrm{pptv}$ ) and high particle masses. As seen in Fig. 9, the time series correlates with the ${ }^{210} \mathrm{~Pb}$ signal $(r=0.66)$, which is a radioactive decay product of ${ }^{222} \mathrm{Rn}$, lending strong support that the air originated from a continental source. Furthermore, the composition of this factor, $60 \%$ sulphate and $35 \%$ organic (see Table 3), is similar to typical aerosol measured in continental regions (Zhang et al., 2007). Finally, this factor contains only $3 \%$ MSA, suggesting that it was uninfluenced by marine sources.

There was less correlation between the time series of this factor and ${ }^{222} \mathrm{Rn}(r=0.15$, see Fig. 10 and Table 4$)$, which has a half-life of approximately 3.8 days (Weast et al., 1983), suggesting that this factor represents air that had not been in contact with land for at least a week. This is supported by the FLEXPART analysis which shows that the air during this time was primarily influenced by the Lincoln Sea north of Ellesmere and Baffin Islands. Similarly, the PSCF analysis shows the greatest contribution from the northern part of Greenland (Fig. 11). The organic component of this factor is aged, with an F44 of 0.25 , which is comparable to the largest value previously reported for continentally-influenced air ( $\mathrm{Ng}$ et al., 2010), consistent with aerosol that has been extensively oxidised in the atmosphere with a long residence time. Although the correlation of the organic component of this factor is greatest with primary marine organic aerosol from Mace Head (see Table 5), this is driven by the dominant signal of this factor at $\mathrm{m} / \mathrm{z} 28$ and $44(r=0.81 \mathrm{ex}-$ cluding these two peaks). The organic mass spectrum correlates slightly less with OOA factors from continental sites $(r=0.75)$ (Ulbrich et al., 2009b; Zhang et al., 2005a) and qualitatively resembles that of aged biomass burning (Capes 


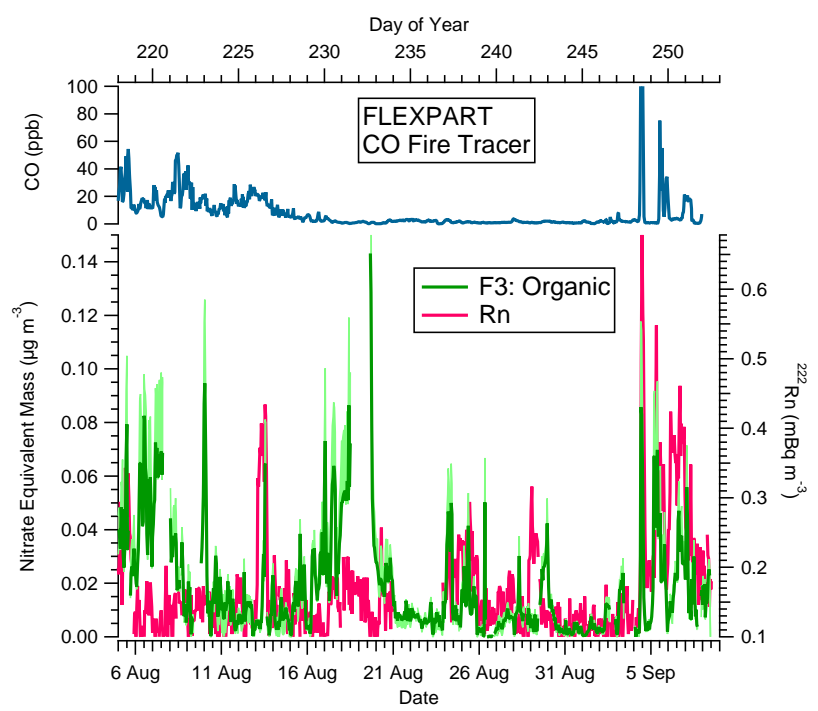

Fig. 10. Time series of the Organic Factor and ${ }^{222} \mathrm{Rn}$ (bottom panel) and the modelled biomass burning contribution of $\mathrm{CO}$ on the measurements (top panel).

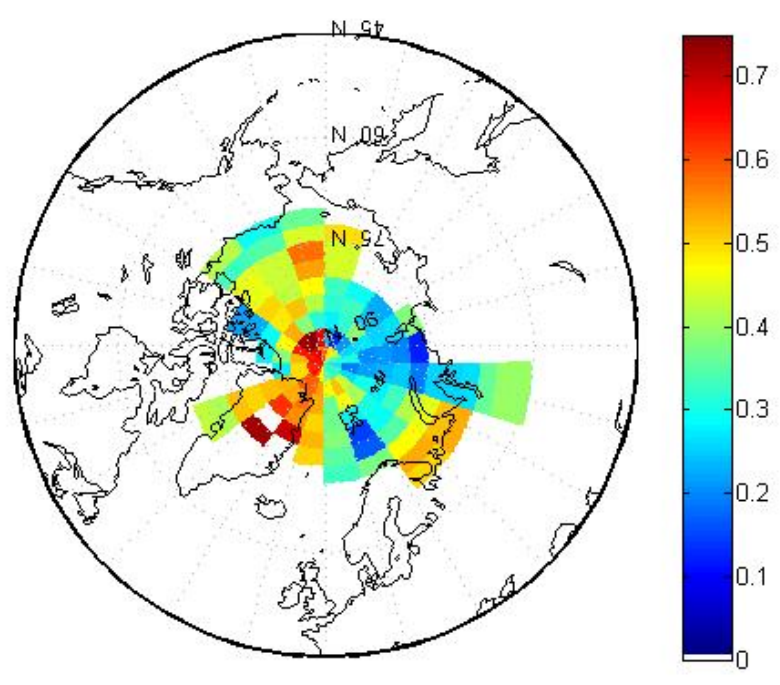

Fig. 11. PSCF analysis of the Continental factor.

et al., 2008). In general, the chemical composition of this factor is consistent with very aged continentally-influenced air that has been transported to the central Arctic in the summer, although the transport pathway is unclear at this time.

\subsubsection{Organic factor}

This factor was thus named because it is $71-88 \%$ organic. It is robust, being present in the factor solution when there are at least three factors. However, the time series does not correlate very well with any measured external tracers, making its source difficult to identify. The mass spectrum of the entire factor, and in particular the organic component (Fig. 8), resembles both that of general oxygenated organic aerosol (OOA) often found from factor analysis of organic aerosol at continental sites as well as the organic mass spectrum of marine organic aerosol (see Table 5 for comparisons). In particular, the mass spectrum is similar to the primary marine organic aerosol measured at Mace Head $(r=0.90)$ (Ovadnevaite et al., 2011). Similar to the Marine Biogenic factor, the organic component of this factor is fairly oxidised, with an F44 of 0.17, and its mass spectrum is similar to that of simple sugars such as glucose and sucrose $(r=0.80$ and 0.79 , respectively) (Russell et al., 2010), consistent with primary marine organic aerosol that are oxygenated, such as mono and polysaccharides (Leck and Bigg, 2007; Russell et al., 2010). Although the correlation with chloride in particles $<10 \mu \mathrm{m}$ diameter measured by cascade impactors is low ( $r=-0.12$, unpublished data), it is possible that submicron primary marine organic aerosol are unassociated with sea salt (Leck and Bigg, 2005a; Bigg and Leck, 2008). However, other studies have found it difficult to conclusively identify primary marine organic aerosol with an AMS (Frossard et al., 2011; Hawkins et al., 2010).

The other possible source of this aerosol is from continents. Figure 10 shows the ${ }^{222} \mathrm{Rn}$ and the Organic Factor, both on a one hour time scale. There is good agreement at the end of the study (4-6 September, DOY 248-250), suggesting that as the ship approached the MIZ, the aerosol was more likely influenced by continental sources. In particular, comparison with the time series of the $\mathrm{CO}$ fire tracer from FLEXPART (Fig. 10), which models the impact of biomass burning on the air sampled by the Oden, would suggest that the sampled air was influenced by biomass burning in Europe (Fig. 12 where red dots represent fires detected by MODIS). The mass spectrum of this factor is consistent with that of aged biomass burning aerosol, which is similar to that of OOA (Capes et al., 2008; Grieshop et al., 2009). However, acetonitrile, which is often used as a fire tracer and was measured by the PTR-TOF, did not peak at this time. In addition, the agreement is not as good for the remainder of the study, suggesting other sources.

The mass spectrum of this factor is similar to that of the continentally-influenced OOA identified during ICEALOT in the North Atlantic Ocean $(r=0.92)$ as well as the unidentified F3 $(r=0.84)$ (Frossard et al., 2011). It is also similar to OOA from urban locations $(r=0.87)$ (Ulbrich et al., 2009b; Zhang et al., 2005a). OOA factors identified at continental sites typically form from the chemical aging of gaseous emissions originating from anthropogenic sources (e.g. $\mathrm{Ng}$ et al., 2010; Zhang et al., 2007) or biogenic sources (e.g. Chen et al., 2009; Slowik et al., 2010) that condense onto particles. PSCF analysis shows contribution from northern Europe in addition to contribution from west of the Queen Elizabeth Islands, north of the Beaufort sea, as well as the area around the Kara sea (see Fig. 13). At this time, the source of this aerosol is unclear and it is possible that it is a combination of various sources transported to the Arctic and whose original sources 
can no longer be separated. Overall, this factor has very little inorganic component, demonstrating that there is a source of Arctic organic aerosol that is not associated with sulphate. In particular, if the aerosol had arisen from a purely biogenic continental region or from highly aged biomass burning, then it is conceivable that it would have little sulphate, nitrate, etc. That being said, the lack of a correlation with such typical continental tracers makes it tempting to believe this factor has a primary marine organic source.

\subsubsection{Ship emission factor}

The time series for this factor is characterised by low signals for most of this campaign with intermittent periods of high loading which coincide with times when the pollution record, comprised of toluene, benzene and particle concentrations, indicated that the air was at risk of being contaminated by ship exhaust. The mass spectrum (Fig. 8) qualitatively resembles that of ship fumigation periods measured by Phinney et al. (2006), as well as hydrocarbon-like organic aerosol from urban sites ( $r \geq 0.93$ ) (Lanz et al., 2007; U1brich et al., 2009b; Zhang et al., 2005b) which are thought to be primary aerosol emitted from vehicular traffic and whose mass spectra are similar to that of lubricating oil $(r=0.98)$ (Canagaratna et al., 2004; Ulbrich et al., 2009b). This factor helped identify when the aerosol was affected by ship emissions and by excluding it, allows us to consider the ambient central Arctic Ocean aerosol without interference. There are some spikes in the Continental and Organic factors that coincide with signal in the Ship Emission factor, showing that the separation between these factors was not perfect. However, given that the signal of the Ship Emission factor was at times 20 times greater than the signal from the ambient factors, the spikes are $<2 \%$ of the mass in either of these factors, and the structure of the time series is still distinct, the impact on the ambient factors was considered insignificant.

\section{Conclusions}

From 5 August to 8 September 2008, non-refractory submicron aerosol particles in the central Arctic Ocean were composed of approximately equal amounts of organic and sulphate components. These particles were influenced by both marine biogenic and continental sources (33\% and $36 \%$ of the sampled ambient aerosol mass, respectively), as determined using PMF. Aerosol from both of these sources were predominantly composed of sulphate, and $47 \%$ of the total sulphate was apportioned to marine biogenic sources while $48 \%$ was apportioned to continental sources. There also appears to be aerosol that was almost purely organic (31\% of the sampled ambient aerosol mass), although it was not possible to conclusively identify a single source for this aerosol at this time, with primary marine and/or aged continental origins possible. The combination of poor correlations to
Footprint Sensitivity: AIRTRACER

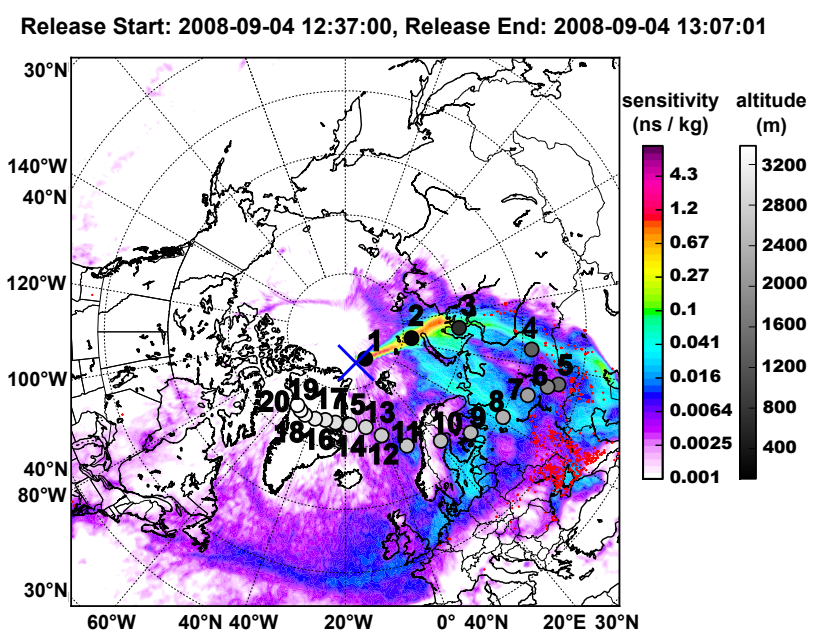

Fig. 12. FLEXPART modelled footprint potential emission sensitivity for 4 September 2008, 12:37 (DOY 248.5). The Oden's position is marked by the blue cross and the red dots represent fires detected by MODIS.

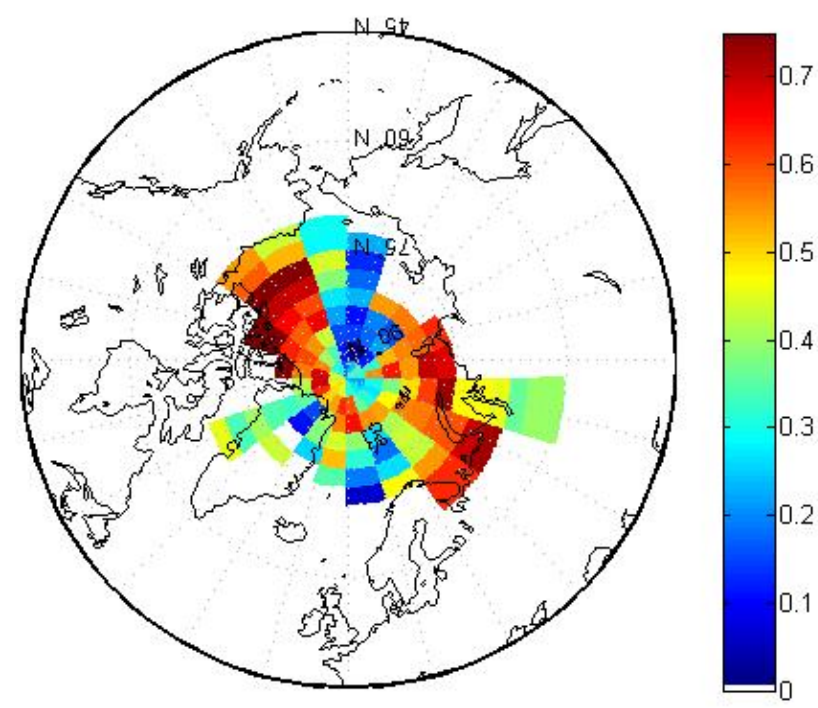

Fig. 13. PSCF analysis of the Organic factor.

typical continental tracers and the similarity of the spectrum to primary organic aerosol measured at Mace Head (Ovadnevaite et al., 2011) suggest a marine origin, although contributions from aged continental origins cannot be ruled out. These results show that up to $1 / 3$ to $2 / 3$ of the summer Arctic submicron aerosol mass is formed from marine sources in the central Arctic basin including the pack ice, MIZ and surrounding open ocean, and that Arctic models that only include aerosol transport from anthropogenic sources in the 
summer could be neglecting a significant mass. This is in contrast to other measurements in the central Arctic free troposphere which at times can be heavily influenced by biomass burning (Brock et al., 2011).

In general, the organic components of all ambient aerosol measured were as oxidised as, if not more than, the OOA component from ground-based continental sites, with an average F44 of $0.18 \pm 0.05$. The organic component of air influenced by continental sources was also found to be more oxidised than that of marine biogenic sources. This is consistent with long range transport of these particles. Although the degree of oxygenation of the organic component of the Marine Biogenic and Organic factors would normally be interpreted as being atmospherically processed, it is possible that in polar marine environments, primary oxygenated organic aerosol particles are emitted directly into the atmosphere, as suggested by previous findings over the pack ice (Leck and Bigg, 2005a). The similarity of the three ambient factors with both primary marine organic aerosol and OOA from continental sites highlights the fact that the aerosol measured in marine environments is oxygenated. In contrast to previous analyses of AMS observations, this study used PMF on the entire mass spectrum, which allowed the inorganics from different sources to be separated, along with their associated organic component.

\section{Supplementary material related to this article is available online at: http://www.atmos-chem-phys.net/11/10619/2011/ acp-11-10619-2011-supplement.pdf.}

Acknowledgements. This work is part of ASCOS (the Arctic Summer Cloud Ocean Study) and was funded by NSERC (including a CGS D for RC) and Arctic-SOLAS (Canada). ASCOS was made possible by funding from the Knut and Alice Wallenberg Foundation and the DAMOCLES European Union 6th Framework Program Integrated Research Project. The Swedish Polar Research Secretariat (SPRS) provided access to the icebreaker Oden and logistical support. We are grateful to the Chief Scientists for planning and coordinating ASCOS, to the SPRS logistical staff and to Oden's Captain Mattias Peterson and his crew. ASCOS is an IPY project under the AICIA-IPY umbrella and an endorsed SOLAS project. Satellite data used in this effort were acquired as part of the activities of NASA's Science Mission Directorate, and are archived and distributed by the Goddard Earth Sciences (GES) Data and Information Services Center (DISC). A. Stohl and J. Burkhart were supported by the Norwegian Research Council as part of the CLIMSLIP project. The authors would like to thank E. Asmi, A. Frossard, D. Orsini and J. Ovadnevaite for data, T. Mauritsen, M. McGuire, R. McWhinney and J. Slowik for helpful discussions, D. Halpin for help setting up and Dr. H.-N. Lee, US DHS/EML, for providing the radon monitor to ASCOS. The authors also wish to acknowledge the NOAA Air Resources Laboratory (ARL) for the provision of the HYSPLIT transport and dispersion model and READY website (http://ready.arl.noaa.gov) used in this publication.
Edited by: I. Brooks

\section{References}

Aiken, A. C., Decarlo, P. F., Kroll, J. H., Worsnop, D. R., Huffman, J. A., Docherty, K. S., Ulbrich, I. M., Mohr, C., Kimmel, J. R., Sueper, D., Sun, Y., Zhang, Q., Trimborn, A., Northway, M., Ziemann, P. J., Canagaratna, M. R., Onasch, T. B., Alfarra, M. R., Prevot, A. S. H., Dommen, J., J., D., Metzger, A., Baltensperger, U., and Jimenez, J. L.: O/C and OM/OC ratios of primary, secondary, and ambient organic aerosols with high-resolution timeof-flight aerosol mass spectrometry, Environ. Sci. Technol., 42, 4478-4485, 2008.

Allan, J. D., Jimenez, J. L., Williams, P. I., Alfarra, M. R., Bower, K. N., Jayne, J. T., Coe, H., and Worsnop, D. R.: Quantitative sampling using an Aerodyne aerosol mass spectrometer 1. Techniques of data interpretation and error analysis, J. Geophys. Res., 108, 4090, doi:10.1029/2002JD002358, 2003.

Allan, J. D., Delia, A. E., Coe, H., Bower, K. N., Alfarra, M. R., Jimenez, J. L., Middlebrook, A. M., Drewnick, F., Onasch, T. B., Canagaratna, M. R., Jayne, J. T., and Worsnop, D. R.: A generalised method for the extraction of chemically resolved mass spectra from Aerodyne aerosol mass spectrometer data, J. Aeros. Sci., 35, 909-922, 2004.

Ashbaugh, L. L., Malm, W. C., and Sadeh, W. Z.: A residence time probability analysis of sulfur concentrations at grand Canyon National Park, Atmos. Environ., 19, 1263-1270, doi:10.1016/00046981(85)90256-2, 1985.

Barone, S. B., Turnipseed, A. A., and Ravishankara, A. R.: Role of Adducts in the Atmospheric Oxidation of Dimethyl Sulfide, Faraday Discuss., 100, 39-54, 1995.

Barrie, L. A.: Arctic air pollution: An overview of current knowledge, Atmos. Environ., 20, 643-663, 1986.

Bates, T. S., Calhoun, J. A., and Quinn, P. K.: Variations in the Methanesulfonate to Sulfate Molar Ratio in Submicrometer Marine Aerosol Particles Over the South Pacific Ocean, J. Geophys. Res., 97, 9859-9865, 1992.

Berresheim, H., Huey, J., Thorn, R., Eisele, F., Tanner, D., and Jefferson, A.: Measurements of dimethyl sulfide, dimethyl sulfoxide, dimethyl sulfone, and aerosol ions at Palmer Station, Antarctica, J. Geophys. Res., 103, 1629-1637, 1998.

Bigg, E. K. and Leck, C.: Cloud-active particles over the central Arctic Ocean, J. Geophys. Res., 106, 32155-32166, 2001.

Bigg, E. K. and Leck, C.: The composition of fragments of bubbles bursting at the ocean surface, J. Geophys. Res., 113, D11209, doi:10.1029/2007JD009, 078, 2008.

Bigg, E. K., Leck, C., and Tranvik, L.: Particulates of the surface microlayer of open water in the central Arctic Ocean in summer, Mar. Chem., 91, 131-141, 2004.

Brock, C. A., Cozic, J., Bahreini, R., Froyd, K. D., Middlebrook, A. M., McComiskey, A., Brioude, J., Cooper, O. R., Stohl, A., Aikin, K. C., de Gouw, J. A., Fahey, D. W., Ferrare, R. A., Gao, R.-S., Gore, W., Holloway, J. S., Hbler, G., Jefferson, A., Lack, D. A., Lance, S., Moore, R. H., Murphy, D. M., Nenes, A., Novelli, P. C., Nowak, J. B., Ogren, J. A., Peischl, J., Pierce, R. B., Pilewskie, P., Quinn, P. K., Ryerson, T. B., Schmidt, K. S., Schwarz, J. P., Sodemann, H., Spackman, J. R., Stark, H., Thomson, D. S., Thornberry, T., Veres, P., Watts, L. A., Warneke, 
C., and Wollny, A. G.: Characteristics, sources, and transport of aerosols measured in spring 2008 during the aerosol, radiation, and cloud processes affecting Arctic Climate (ARCPAC) Project, Atmos. Chem. Phys., 11, 2423-2453, doi:10.5194/acp-11-24232011, 2011.

Canagaratna, M. R., Jayne, J. T., Ghertner, D. A., Herndon, S., Shi, Q., Jimenez, J. L., Silva, P. J., Williams, P., Lanni, T., Drewnick, F., Demerjian, K. L., Kolb, C. E., and Worsnop, D. R.: Chase Studies of Particulate Emissions from in-use New York City Vehicles, Aerosol Sci. Tech., 38, 555-573, 2004.

Canagaratna, M. R., Jayne, J. T., Jimenez, J. L., Allan, J. D., Alfarra, M. R., Zhang, Q., Onasch, T. B., Drewnick, F., Coe, H., Middlebrook, A. M., Delia, A. E., Williams, L. R., Trimborn, A. M., Northway, M. J., DeCarlo, P. F., Kolb, C. E., Davidovits, P., and Worsnop, D. R.: Chemical and microphysical characterization of ambient aerosols with the Aerodyne aerosol mass spectrometer, Mass Spec. Rev., 26, 185-222, 2007.

Capes, G., Johnson, B., McFiggans, G., Williams, P. I., Haywood, J., and Coe, H.: Aging of biomass burning aerosols over West Africa: Aircraft measurements of chemical composition, microphysical properties, and emission ratios, J. Geophys. Res., 113, D00C15, doi:10.1029/2008JD009, 845, 2008.

Ceburnis, D., O’Dowd, C. D., Jennings, G. S., Facchini, M. C., Emblico, L., Decesari, S., Fuzzi, S., and Sakalys, J.: Marine aerosol chemistry gradients: Elucidating primary and secondary processes and fluxes, Geophys. Res. Lett., 35, L07804, doi:10.1029/2008GL033462, 2008.

Chang, R.-W., Gao, Q., Hillamo, R., Teinila, K., Orsini, D., Leaitch, W., Leck, C., and Abbatt, J.: Aerosol mass closure during ASCOS, in preparation, 2011.

Chen, Q., Farmer, D. K., Schneider, J., Zorn, S. R., Heald, C. L., Karl, T. G., Guenther, A., Allan, J. D., Robinson, N., Coe, H., Kimmel, J. R., Pauliquevis, T., Borrmann, S., Pöschl, U., Andreae, M. O., Artaxo, P., Jimenez, J. L., and Martin, S. T.: Mass spectral characterization of submicron biogenic organic particles in the Amazon Basin, Geophys. Res. Lett., 36, L20 806, doi:10.1029/2009GL039, 880, 2009.

Chin, M., Jacob, D. J., Gardner, G. M., Foreman-Fowler, M. S., Spiro, P. A., and Savoie, D. L.: A global three-dimensional model of tropospheric sulfate, J. Geophys. Res., 101, $18667-$ $18690,1996$.

Chin, W.-C., Orellana, M. V., and Verdugo, P.: Spontaneous assembly of marine dissolved organic matter into polymer gels, Nature, 391, 568-572, 1998.

Covert, D. S., Wiedensohler, A., Aalto, P., Heintzenberg, J., McMurry, P., and Leck, C.: Aerosol number size distributions from 3 to $500 \mathrm{~nm}$ diameter in the arctic marine boundary layer during summer and autumn, Tellus, 48B, 197-212, 1996.

de Gouw, J. and Warneke, C.: Measurements of volatile organic compounds in the earths atmosphere using proton-transferreaction mass spectrometry, Mass Spec. Rev., 26, 223-257, 2007.

Draxler, R. R. and Rolph, G. D.: HYSPLIT (HYbrid Single-Particle Lagrangian Integrated Trajectory) Model access via NOAA ARL READY Website (http://ready.arl.noaa.gov/HYSPLIT.php), last access: 21 September 2010, 2010.

Drewnick, F., Hings, S. S., DeCarlo, P., Jayne, J. T., Gonin, M., Fuhrer, K., Weimer, S., Jimenez, J. L., Demerjian, K. L., Borrmann, S., and Worsnop, D. R.: A new time-of-flight aerosol mass spectrometer (TOF-AMS) - Instrument description and first field deployment, Aerosol Sci. Technol., 39, 637-658, 2005.

Facchini, M. C., Rinaldi, M., Decesari, S., Carbone, C., Finessi, E., Mircea, M., Fuzzi, S., Ceburnis, D., Flanagan, R., Nilsson, E. D., de Leeuw, G., Martino, M., Woeltjen, J., and O'Dowd, C. D.: Primary submicron marine aerosol dominated by insoluble organic colloids and aggregates, Geophys. Res. Lett., 35, L17 814, doi:10.1029/2008GL034, 210, 2008.

Feldman, G. C. and McClain, C. R.: Ocean Color Web, Aqua MODIS Monthly Chlorophyll concentration, http://oceancolor.gsfc.nasa.gov/cgi/13/A20082142008244.

L3m_MO_CHL_chlor_a_9km.png?sub=img, last access: 5 July 2010, 2008.

Forster, C., Stohl, A., and Seibert, P.: Parameterization of convective transport in a Lagrangian particle dispersion model and its evaluation, J. Appl. Meteorol. Clim., 46, 403-422, 2007.

Frossard, A. A., Shaw, P. M., Russell, L. M., Kroll, J. H., Canagaratna, M. R., Worsnop, D. R., Quinn, P. K., and Bates, T. S.: Springtime Arctic haze contributions of submicron organic particles from European and Asian combustion sources, J. Geophys. Res., 116, D05 205, doi:10.1029/2010JD015, 178, 2011.

Fu, P., Kawamura, K., Chen, J., and Barrie, L.: Isoprene, Monoterpene, and Sesquiterpene Oxidation Products in the High Arctic Aerosols during Late Winter to Early Summer, Environ. Sci. Tech., 43, 4022-4028, 2009.

Garrett, T. J. and Zhao, C.: Increased Arctic cloud longwave emissivity associated with pollution from mid-latitudes, Nature, 440 787-789, 2006.

Garrett, T. J., Radke, L. F., and Hobbs, P. V.: Aerosol Effects on Cloud Emissivity and Surface Longwave Heating in the Arctic, J. Atmos. Sci., 59, 769-778, 2002.

Gondwe, M., Krol, M., Klaassen, W., Gieskes, W., and de Baar, H.: Comparison of modeled versus measured MSA:nss $\mathrm{SO}_{4}^{=}$ratios: A global analysis, Global Biogeochem. Cy., 18, GB2006, doi:10.1029/2003GB002, 144, 2004.

Gong, S. L., Zhao, T. L., Sharma, S., Toom-Sauntry, D., Lavoue, D., Zhang, X. B., Leaitch, W., and Barrie, L. A.: Identification of trends and interannual variability of sulfate and black carbon in the Canadian High Arctic: 1981-2007, J. Geophys. Res., 115, D07 305, doi:10.1029/2009JD012, 943, 2010.

Graus, M., Müller, M., and Hansel, A.: High Resolution PTR-TOF: Quantification and Formula Confirmation of VOC in Real Time, J. Amer. Soc. Mass Spectr., 21, 1037-1044, 2010.

Grieshop, A. P., Donahue, N. M., and Robinson, A. L.: Laboratory investigation of photochemical oxidation of organic aerosol from wood fires 2: analysis of aerosol mass spectrometer data, Atmos. Chem. Phys., 9, 2227-2240, doi:10.5194/acp-9-2227-2009, 2009.

Hawkins, L. N. and Russell, L. M.: Polysaccharides, Proteins, and Phytoplankton Fragments: Four Chemically Distinct Types of Marine Primary Organic Aerosol Classified by Single Particle Spectromicroscopy, Advances in Meteorology, 2010, 612 132, doi:10.1155/2010/612, 132, 2010.

Hawkins, L. N., Russell, L. M., Covert, D. S., Quinn, P. K., and Bates, T. S.: Carboxylic acids, sulfates, and organosulfates in processed continental organic aerosol over the southeast $\mathrm{Pa}$ cific Ocean during VOCALS-REx 2008, J. Geophys. Res., 115, D13 201, doi:10.1029/2009JD013,276, 2010.

Heintzenberg, J. and Leck, C.: Seasonal variation of the 
atmospheric aerosol near the top of the marine boundary layer over Spitsbergen related to the Arctic sulphur cycle, Tellus, 46B, 52-67, 1994.

Hillamo, R., Kerminen, V.-M., Aurela, M., Makela, T., Maenhaut, W., and Leck, C.: Modal structure of chemical mass size distributions in the high Arctic aerosol, J. Geophys. Res., 106, 2755527571, 2001.

Hopke, P. K., Chong, C. L., W., C., and Landsberger, S.: The use of bootstrapping to estimate conditional probability fields for source locations of airborne pollutants, Chemometr. Intell. Lab., 30, 69-79, 1995.

Hutter, A. R., Larsen, R. J., Maring, H., and Merrill, J. T.: ${ }^{222}$ Rn at Bermuda and Mauna Loa: Local and Distant Sources, J. Radioanal. Nucl. Chem., 193, 309-318, 1995.

Hynes, A. J., Wine, P. H., and Semmes, D. H.: Kinetics and mechanism of hydroxyl reactions with organic sulfides, J. Phys. Chem., 90, 4148-4156, 1986.

Jayne, J., Leard, D., Zhang, X., Davidovits, P., Smith, K., Kolb, C., and Worsnop, D.: Development of an Aerosol Mass Spectrometer for Size and Composition Analysis of Submicron Particles, Aerosol Sci. Tech., 33, 49-70, 2000.

Jefferson, A., Tanner, D. J., Eisele, F. L., Davis, D. D., Cheng, G., Crawford, J., Huey, J. W., Torres, A. L., and Berresheim, H.: $\mathrm{OH}$ photochemistry and methane sulfonic acid formation in the coastal Antarctic boundary layer, J. Geophys. Res., 103, 16471656, 1998.

Jimenez, J., Jayne, J., Shi, Q., Kolb, C., Worsnop, D., Yourshaw, I., Seinfeld, J., Flagan, R., Zhang, X., Smith, K., Morris, J., and Davidovits, P.: Ambient aerosol sampling using the Aerodyne Aerosol Mass Spectrometer, J. Geophys. Res., 108, 8425, doi:10.1029/2001JD001, 213, 2003.

Karl, M., Gross, A., Leck, C., and Pirjola, L.: Intercomparison of dimethylsulfide oxidation mechanisms for the marine boundary layer: Gaseous and particulate sulfur constituents, J. Geophys. Res., 112, D15304, doi:10.1029/2006JD007, 914, 2007.

Kerminen, V.-M. and Leck, C.: Sulfur chemistry over the central Arctic Ocean during the summer: Gas-to-particle transformation, J. Geophys. Res., 106, 32087-32099, 2001.

Kostenidou, E., Pathak, R. K., and Pandis, S. N.: An Algorithm for the Calculation of Secondary Organic Aerosol Density Combining AMS and SMPS Data, Aerosol Sci. Technol., 41, 1002-1010, 2007.

Kreidenweis, S. M., Yin, F., Wang, S.-C., Grosjean, D., Flagan, R. C., and Seinfeld, J. H.: Aerosol formation during photooxidation of organosulfur species, Atmos. Env. A-Gen., 25, 24912500, 1991.

Kuhn, T., Damoah, R., Bacak, A., and Sloan, J. J.: Characterising aerosol transport into the Canadian High Arctic using aerosol mass spectrometry and Lagrangian modelling, Atmos. Chem. Phys., 10, 10489-10502, doi:10.5194/acp-10-10489-2010, 2010.

Langley, L., Leaitch, W. R., Lohmann, U., Shantz, N. C., and Worsnop, D. R.: Contributions from DMS and ship emissions to $\mathrm{CCN}$ observed over the summertime North Pacific, Atmos. Chem. Phys., 10, 1287-1314, doi:10.5194/acp-10-1287-2010, 2010.

Lanz, V. A., Alfarra, M. R., Baltensperger, U., Buchmann, B., Hueglin, C., and Prévôt, A. S. H.: Source apportionment of submicron organic aerosols at an urban site by factor analytical modelling of aerosol mass spectra, Atmos. Chem. Phys., 7,
1503-1522, doi:10.5194/acp-7-1503-2007, 2007.

Law, K. S. and Stohl, A.: Arctic Air Pollution: Origins and Impacts, Science, 315, 1537-1541, 2007.

Leaitch, W. R., Barrie, L. A., Bottenheim, J. W., Li, S. M., Shepson, P. B., Muthuramu, K., and Yokouchi, Y.: Airborne observations related to ozone depletion at polar sunrise, J. Geophys. Res., 99, 25499-25517, 1994.

Leck, C. and Bigg, E. K.: Biogenic particles in the surface microlayer and overlaying atmosphere in the central Arctic Ocean during summer, Tellus, 57B, 305-316, 2005a.

Leck, C. and Bigg, E. K.: Source and evolution of the marine aerosol-A new perspective, Geophys. Res. Lett., 32, L19803, doi:10.1029/2005GL023651, 2005b.

Leck, C. and Bigg, E. K.: A modified aerosol-cloud-climate feedback hypothesis, Environ. Chem., 4, 400-403, 2007.

Leck, C. and Bigg, E. K.: New Particle Formation of Marine Biological Origin, Aerosol Sci. Tech., 44, 570-577, 2010.

Leck, C. and Persson, C.: Seasonal and short-term variability in dimethyl sulfide, sulfur dioxide and biogenic sulfur and sea salt aerosol particles in the arctic marine boundary layer during summer and autumn, Tellus B, 48, 272-299, 1996.

Leck, C., Bigg, E. K., Covert, D. S., Heintzenberg, J., Maenhaut, W., Nilsson, E. D., and Wiedensohler, A.: Overview of the atmospheric research program during the International Arctic Ocean Expedition of 1991 (IAOE-91) and its scientific results, Tellus B, 48, 136-155, 1996.

Leck, C., Nilsson, E. D., Bigg, E. K., and Backlin, L.: Atmospheric program on the Arctic Ocean Expedition 1996 (AOE-96): An overview of scientific goals, experimental approaches, and instruments, J. Geophys. Res., 106, 32051-32067, 2001.

Leck, C., Hetinzenberg, J., and Engard, M.: A meridional profile of the chemical composition of submicrometer particles over the Atlantic Ocean: aerosol sources and hemispheric variabilities, Tellus B, 54, 377-384, 2002a.

Leck, C., Norman, M., and Bigg, E. K.: Chemical composition and sources of the high Arctic aerosol relevant for cloud formation, J. Geophys. Res., 107, 4135, doi:10.1029/2001JD001, 463, $2002 \mathrm{~b}$.

Leck, C., Tjernström, M., Swietlicki, E., and Bigg, E. K.: Can Marine Micro-organisms Influence Melting of the Arctic Pack Ice?, Eos Trans., 85, 25-36, 2004.

Li, S.-M. and Barrie, L. A.: Biogenic Sulfur Aerosol in the Arctic Troposphere: 1. Contributions to Total Sulfate, J. Geophys. Res., 98, 20 613-20 622, 1993a.

Li, S.-M. and Barrie, L. A.: Biogenic Sulfur in the Arctic Troposphere: 2. Trends and Seasonal Variations, J. Geophys. Res., 98, 20623-20631, 1993b.

Lindinger, W., Hansel, A., and Jordan, A.: On-line monitoring of volatile organic compounds at pptv levels by means of protontransfer-reaction mass spectrometry (PTR-MS) medical applications, food control and environmental research, Int. J. Mass Spectrom., 173, 191-241, 1998.

Liu, P. S., Deng, R., Smith, K. A., Williams, L. R., Jayne, J. T., Canagaratna, M. R., Moore, K., Onasch, T. B., Worsnop, D. R., and Deshler, T.: Transmission Efficiency of an Aerodynamic Focusing Lens System: Comparison of Model Calculations and Laboratory Measurements for the Aerodyne Aerosol Mass Spectrometer, Aerosol Sci. Tech., 41, 721-733, 2007.

Lubin, D. and Vogelmann, A. M.: Expected magnitude of the aerosol shortwave indirect effect in springtime Arctic 
liquid water clouds, Geophys. Res. Lett., 34, L11801, doi:10.1029/2006GL028, 750, 2007.

Mattsson, R., Paatero, J., and Hatakka, J.: Automatic alpha beta analyser for air filter samples - Absolute determination of radon progeny by pseudo-coincidence techniques, Radiat. Prot. Dosim., 63, 133-139, 1996.

Mauritsen, T., Sedlar, J., Tjernström, M., Leck, C., Martin, M., Shupe, M., Sjogren, S., Sierau, B., Persson, P. O. G., Brooks, I. M., and Swietlicki, E.: An Arctic CCN-limited cloud-aerosol regime, Atmos. Chem. Phys., 11, 165-173, doi:10.5194/acp-11165-2011, 2011.

Megaw, W. and Flyger, H.: Measurement of the Background Atmospheric Aerosol, Aerosol Sci., 4, 179-181, 1973.

Müller, M., Graus, M., Ruuskanen, T. M., Schnitzhofer, R., Bamberger, I., Kaser, L., Titzmann, T., Hörtnagl, L., Wohlfahrt, G., Karl, T., and Hansel, A.: First eddy covariance flux measurements by PTR-TOF, Atmos. Meas. Tech., 3, 387-395, doi:10.5194/amt-3-387-2010, 2010.

Ng, N. L., Canagaratna, M. R., Zhang, Q., Jimenez, J. L., Tian, J., Ulbrich, I. M., Kroll, J. H., Docherty, K. S., Chhabra, P. S., Bahreini, R., Murphy, S. M., Seinfeld, J. H., Hildebrandt, L., Donahue, N. M., DeCarlo, P. F., Lanz, V. A., Prévôt, A. S. H., Dinar, E., Rudich, Y., and Worsnop, D. R.: Organic aerosol components observed in Northern Hemispheric datasets from Aerosol Mass Spectrometry, Atmos. Chem. Phys., 10, 46254641, doi:10.5194/acp-10-4625-2010, 2010.

Nilsson, E. D. and Leck, C.: A pseudo-Langrangian study of the sulfur budget in the remote Arctic marine boundary layer, Tellus, 54B, 213-230, 2002.

Norman, A. L., Barrie, L. A., Toom-Sauntry, D., Sirois, A., Krouse, H. R., Li, S. M., and Sharma, S.: Sources of aerosol sulphate at Alert: Apportionment using stable isotopes, J. Geophys. Res., 104, 11619-11631, 1999.

O'Dowd, C. D., Facchini, M. C., Cavalli, F., Ceburnis, D., Mircea, M., Decesari, S., Fuzzi, S., Yoon, Y. J., and Putaud, J.-P.: Biogenically driven organic contribution to marine aerosol, Nature, 431, 676-680, 2004.

Olivier, J. G. J. and Berdowski, J. J. M.: Global emission sources and sinks, in: The Climate System, edited by: Berdowski, J., Guicherit, R., and Heij, B. J., 33-78, A.A. Balkema, Lisse, 2001.

Ovadnevaite, J., O'Dowd, C., Dall'Osto, M., Ceburnis, D., Worsnop, D. R., and Berresheim, H.: Detecting high contributions of primary organic matter to marine aerosol: A case study, Geophys. Res. Lett., 38, L02807, doi:10.1029/2010GL046, 083, 2011.

Paatero, P.: Least squares formulation of robus non-negative factor analysis, Chemometr. Intell. Lab., 37, 23-35, 1997.

Paatero, P. and Tapper, U.: Positive matrix factorization: A nonnegative factor model with optimal utilization of error estimates of data values, Environmetrics, 5, 111-126, 1994.

Phinney, L., Leaitch, W. R., Lohmann, U., Boudries, H., Worsnop, D. R., Jayne, J. T., Toom-Sauntry, D., Wadleigh, M., Sharma, S., and Shantz, N. C.: Characterization of the aerosol over the subarctic north east Pacific Ocean, Deep-Sea Res. Pt. II, 53, 2410 2433, 2006

Quinn, P., Shaw, G., Andrews, E., Dutton, E., Ruoho-Airola, T., and Gong, S.: Arctic haze: current trends and knowledge gaps, Tellus, 59B, 99-114, 2007.

Quinn, P. K., Bates, T. S., Schulz, K., and Shaw, G. E.: Decadal trends in aerosol chemical composition at Barrow, Alaska: 19762008, Atmos. Chem. Phys., 9, 8883-8888, doi:10.5194/acp-98883-2009, 2009.

Read, K. A., Lewis, A. C., Bauguitte, S., Rankin, A. M., Salmon, R. A., Wolff, E. W., Saiz-Lopez, A., Bloss, W. J., Heard, D. E., Lee, J. D., and Plane, J. M. C.: DMS and MSA measurements in the Antarctic Boundary Layer: impact of $\mathrm{BrO}$ on MSA production, Atmos. Chem. Phys., 8, 2985-2997, doi:10.5194/acp-82985-2008, 2008.

Rolph, G. D.: Real-time Environmental Applications and Display sYstem (READY) Website (http://ready.arl.noaa.gov), last access: 21 September 2010, 2010.

Russell, L. M., Hawkins, L. N., Frossard, A. A., Quinn, P. K. and Bates, T. S.: Carbohydrate-like composition of submicron atmospheric particles and their production from ocean bubble bursting, Proc. Nat. Acad. Sci., 107, 6652-6657, doi:10.1073/pnas.0908905107, 2010.

Sedlar, J., Tjernstrom, M., Mauritsen, T., Shupe, M. D., Brooks, I. M., Persson, P. O. G., Birch, C. E., Leck, C., Sirevaag, A., and Nicolaus, M.: A transitioning Arctic surface energy budget: the impacts of solar zenith angle, surface albedo and cloud radiative forcing, Clim. Dynam., doi:10.1007/s00382-010-0937-5, 2010.

Shindell, D. T., Chin, M., Dentener, F., Doherty, R. M., Faluvegi, G., Fiore, A. M., Hess, P., Koch, D. M., MacKenzie, I. A., Sanderson, M. G., Schultz, M. G., Schulz, M., Stevenson, D. S., Teich, H., Textor, C., Wild, O., Bergmann, D. J., Bey, I., Bian, H., Cuvelier, C., Duncan, B. N., Folberth, G., Horowitz, L. W., Jonson, J., Kaminski, J. W., Marmer, E., Park, R., Pringle, K. J., Schroeder, S., Szopa, S., Takemura, T., Zeng, G., Keating, T. J., and Zuber, A.: A multi-model assessment of pollution transport to the Arctic, Atmos. Chem. Phys., 8, 5353-5372, doi:10.5194/acp-8-5353-2008, 2008.

Shupe, M. D. and Intrieri, J. M.: Cloud Radiative Forcing of the Arctic Surface: The Influence of Cloud Properties, Surface Albedo, and Solar Zenith Angle, J. Clim., 17, 616-628, 2004.

Slowik, J. G., Stroud, C., Bottenheim, J. W., Brickell, P. C., Chang, R. Y.-W., Liggio, J., Makar, P. A., Martin, R. V., Moran, M. D., Shantz, N. C., Sjostedt, S. J., van Donkelaar, A., Vlasenko, A., Wiebe, H. A., Xia, A. G., Zhang, J., Leaitch, W. R., and Abbatt, J. P. D.: Characterization of a large biogenic secondary organic aerosol event from eastern Canadian forests, Atmos. Chem. Phys., 10, 2825-2845, doi:10.5194/acp-10-2825-2010, 2010.

Stohl, A., Hittenberger, M., and Wotawa, G.: Validation of the Lagrangian particle dispersion model FLEXPART against large scale tracer experiments, Atmos. Environ., 32, 4245-4264, 1998.

Stohl, A., Forster, C., Eckhardt, S., Spichtinger, N., Huntrieser, H., Heland, J., Schlager, H., Wilhelm, S., Arnold, F., and Cooper, O.: A backward modeling study of intercontinental pollution transport using aircraft measurements, J. Geophys. Res., 108, 4370, doi:10.1029/2002JD002, 862, 2003.

Stohl, A., Forster, C., Frank, A., Seibert, P., and Wotawa, G.: Technical note: The Lagrangian particle dispersion model FLEXPART version 6.2, Atmos. Chem. Phys., 5, 2461-2474, doi:10.5194/acp-5-2461-2005, 2005.

Stohl, A., Berg, T., Burkhart, J. F., Fjæraa, A. M., Forster, C., Herber, A., Hov, Ø., Lunder, C., McMillan, W. W., Oltmans, S., Shiobara, M., Simpson, D., Solberg, S., Stebel, K., Ström, J., Tørseth, K., Treffeisen, R., Virkkunen, K., and Yttri, K. E.: Arctic smoke - record high air pollution levels in the European Arctic 
due to agricultural fires in Eastern Europe in spring 2006, Atmos. Chem. Phys., 7, 511-534, doi:10.5194/acp-7-511-2007, 2007.

Tjernström, M.: The Summer Arctic Boundary Layer During the Arctic Ocean Experiment 2001 (AOE-2001), Bound.-Lay. Meteorol., 117, 5-36, 2005.

Turnipseed, A. A., Barone, S. B., and Ravishankara, A. R.: Reaction of $\mathrm{OH}$ with Dimethyl Sulfide. 2. Products and Mechanisms, J. Phys. Chem., 100, 14703-14713, 1996.

Twomey, S.: The Influence of Pollution on the Shortwave Albedo of Clouds, J. Atmos. Sci., 34, 1149-1152, 1977.

Ulbrich, I. M., Canagaratna, M. R., Zhang, Q., Worsnop, D. R., and Jimenez, J. L.: Interpretation of organic components from Positive Matrix Factorization of aerosol mass spectrometric data, Atmos. Chem. Phys., 9, 2891-2918, doi:10.5194/acp-9-2891-2009, 2009a.

Ulbrich, I., Lechner, M., and Jimenez, J.: AMS Spectral Database, http://cires.colorado.edu/jimenez-group/AMSsd/, last access: 30 June 2010, 2009b.

Wang, X. and Key, J. R.: Recent Trends in Arctic Surface, Cloud, and Radiation Properties from Space, Science, 299, 1725-1728, 2003.

Weast, R. C., Astle, M. J., and Beyer, W. H. (eds.): CRC Handbook of Chemistry and Physics, 64th edn., CRC Press, Inc., Boca Raton, Florida, 1983.

Xie, Z., Sun, L., Blum, J. D., Huang, Y., and He, W.: Summertime aerosol chemical components in the marine boundary layer of the Arctic Ocean, J. Geophys. Res., 111, D10309, doi:10.1029/2005JD006, 253, 2006.

Yin, F., Grosjean, D., Flagan, R. C., and Seinfeld, J. H.: Photooxidation of dimethyl sulfide and dimethyl disulfide. II: Mechanism evaluation, J. Atmos. Chem., 11, 365-399, 1990a.

Yin, F., Grosjean, D., and Seinfeld, J. H.: Photooxidation of dimethyl sulfide and dimethyl disulfide. I: Mechanism development, J. Atmos. Chem., 11, 309-364, 1990b.

Yli-Tuomi, T., Hopke, P. K., Paatero, P., Basunia, M. S., Landsberger, S., Viisanen, Y., and Paatero, J.: Atmospheric aerosol over Finnish Arctic: source analysis by the multilinear engine and the potential source contribution function, Atmos. Environ., 37, 4381-4392, 2003.
Zhang, G., Li, J., Li, X., Xu, Y., Guo, L., Tang, J., Lee, C., Liu, $\mathrm{X}$., and Chen, Y.: Impact of anthropogenic emissions and open biomass burning on regional carbonaceous aerosols in South China, Environ. Poll., 158, 3392-3400, 2010.

Zhang, Q., Alfarra, M. R., Worsnop, D. R., Allan, J. D., Coe, H., Canagaratna, M. R., and Jimenez, J. L.: Deconvolution and Quantification of Hydrocarbon-like and Oxygenated Organic Aerosols Based on Aerosol Mass Spectrometry, Environ. Sci. Technol., 39, 4938-4952, 2005a.

Zhang, Q., Worsnop, D. R., Canagaratna, M. R., and Jimenez, J. L.: Hydrocarbon-like and oxygenated organic aerosols in Pittsburgh: insights into sources and processes of organic aerosols, Atmos. Chem. Phys., 5, 3289-3311, doi:10.5194/acp-5-32892005, 2005b.

Zhang, Q., Jimenez, J. L., Canagaratna, M. R., Allan, J. D., Coe, H., Ulbrich, I., Alfarra, M., Takami, A., Middlebrook, A. M., Sun, Y., Dzepina, K., Dunlea, E., Docherty, K., DeCarlo, P. F., D., S., Onasch, T. B., Jayne, J., Miyoshi, T., Shimono, A., Hatakeyama, S., Takegawa, N., Kondo, Y., Schneider, J., Drewnick, F., Borrmann, S., Weimer, S., Demerjian, K., Williams, P., Bower, K., Bahreini, R., Cottrell, L., Griffin, R. J., Rautiainen, J., Sun, J., Zhang, Y., and Worsnop, D.: Ubiquity and dominance of oxygenated species in organic aerosols in anthropogenicallyinfluenced Northern Hemisphere midlatitudes, Geophys. Res. Lett., 34, L13 801, doi:10.1029/2007GL029, 979, 2007.

Ziemba, L. D., Dibb, J. E., Griffin, R. J., Huey, L. G., and Beckman, P. J.: Observations of particle growth at a remote, Arctic site, Atmos. Environ., 44, 1649-1657, 2010.

Zorn, S. R., Drewnick, F., Schott, M., Hoffmann, T., and Borrmann, S.: Characterization of the South Atlantic marine boundary layer aerosol using an aerodyne aerosol mass spectrometer, Atmos. Chem. Phys., 8, 4711-4728, doi:10.5194/acp-8-47112008, 2008. 